\title{
The amphipod scavenging guild in two Arctic fjords: seasonal variations, abundance and trophic interactions
}

\author{
Henrik Nygård ${ }^{1,2, *}$, Jørgen Berge ${ }^{1,2}$, Janne E. Søreide ${ }^{1}$, Mikko Vihtakari ${ }^{2,3}$, \\ Stig Falk-Petersen ${ }^{3}$
}

\author{
${ }^{1}$ The University Centre in Svalbard, 9171 Longyearbyen, Norway \\ ${ }^{2}$ Faculty of Biosciences, Fisheries and Economics, University of Tromsø, 9037 Tromsø, Norway \\ ${ }^{3}$ Norwegian Polar Institute, Polar Environmental Centre, 9296 Tromsø, Norway
}

\begin{abstract}
Scavenging amphipods are important for the circulation and dispersal of organic material in the marine environment. Despite their dominance in the scavenging guild and importance in the food web, little is known about Arctic amphipods and their feeding preferences. We studied the amphipod scavenging guild using baited traps for one full year to increase our understanding of its seasonal variations. Two Arctic fjords with contrasting hydrographical conditions were studied: Adventfjorden, which is influenced by Atlantic water inflow, and Rijpfjorden, which is dominated by cold Arctic water masses. The species composition clearly differed between the 2 fjords. Onisimus caricus, followed by Anonyx laticoxae, were the dominant species in Adventfjorden. In Rijpfjorden, the species diversity was higher, particularly for Anonyx spp. In both fjords, a clear depth zonation in species distribution was detected, with a seasonal dynamic in species composition. A seasonal pattern in catch sizes was observed in both fjords. The timing of this pattern varied, likely because of the climatic differences between the fjords. Lipid content, lipid classes and fatty acid composition were analyzed for $A$. nugax, $O$. caricus, O. litoralis, $O$. nanseni and $O$. glacialis, and stable isotopes were also analyzed for the all these species except $O$. glacialis. A clear difference in the fatty acid and stable isotope composition was found among species. $O$. glacialis and $O$. litoralis were primarily omnivorous-herbivorous, while the other species were predominantly carnivorous. O. nanseni and A. nugax preyed extensively on calanoid copepods (Calanus spp.) whereas O. caricus did not.
\end{abstract}

KEY WORDS: Scavenger · Lysianassoid amphipods · Onisimus spp. · Anonyx spp. · Seasonality Lipid content $\cdot$ Fatty acid composition $\cdot$ Stable isotope analysis

\section{INTRODUCTION}

Scavenging animals feed on dead organisms and play a key role in circulating and dispersing organic material from food falls (Britton \& Morton 1994). In the marine environment, only a few species show adaptations suitable for an obligate scavenging feeding mode, as carrion are a scarce food source in comparison to the vast area of the oceans (Britton \& Morton 1994, Dauby et al. 2001, De Broyer et al. 2004).
Thus, most marine necrophagous species are facultative scavengers with an omnivorous diet, also being predators or detrivores (Sainte-Marie 1984, Slattery \& Oliver 1986, Sainte-Marie et al. 1989, Legeżyńska 2001, 2008). Lysianassoid amphipods are a speciesrich group that appears to be especially important as scavengers in polar and cold waters, as well as in the deep sea (Vader \& Romppainen 1985, Legeżyńska et al. 2000, De Broyer et al. 2004, Premke et al. 2006). Many of the deep-sea lysianassoid amphipods are 
especially adapted to scavenging, with specialized mouthparts and an alimentary tract suited for accumulation and storage of food (Dahl 1979, De Broyer et al. 2004). However, shallow-water lysianassoid amphipods seem to be less specialized and are likely to have broader diets (Sainte-Marie 1984, Slattery \& Oliver 1986).

In the Arctic, lysianassoid amphipods dominate the necrophagous fauna (Legeżyńska et al. 2000). In Svalbard fjords, lysianassoid amphipods dominate the invertebrate macrofauna; for example, on tidal flats Onisimus litoralis constitute up to $95 \%$ of the total macrofauna density (Węsławski et al. 2000). Several studies have focused on species distribution, feeding behavior and life history traits of scavenging amphipods both in the deep sea and in shallow coastal areas (e.g. Węsławski et al. 1991, Legeżyńska et al. 2000, Legeżyńska 2001, 2008, Węsławski \& Legeżyńska 2002, Premke et al. 2006), but few studies have had a year-round sampling approach and thus comprehensive information on seasonality in the amphipod scavenging guild is lacking.

Although scavenging fauna are expected to be omnivorous and thus not directly dependent on highly seasonal primary production, processes related to the life history of scavenger species might imply seasonal variation in baited trap catches. Ontogenic processes among the different lysianassoid amphipods, such as timing of the life cycle, increased activity prior to mating, reduced appetite among egg-carrying females or brood release (e.g. Sainte-Marie et al. 1989, 1990, Conlan 1991, Nygård et al. 2009), can influence not only catch sizes, but also species composition in the samples in different seasons. Moore \& Wong (1995) report a seasonal pattern in abundance of Orchomene nanus in baited traps from Scotland, with the highest abundance in autumn. In a study from Antarctica, Smale et al. (2007) found large differences in the scavenging guild between winter and summer, especially in the abundance of amphipods, suggesting a seasonal change in feeding behavior. No such large variations have been reported from the Arctic, even though sampling has been conducted year-round (Legeżyńska et al. 2000). In the present study, we attempt to describe seasonal variation in the amphipod scavenging guild by using a high temporal resolution in sampling.

Amphipods form a key component in polar food webs, transferring and recycling organic material to higher trophic levels (TLs, Jarre-Teichmann et al. 1997, Dauby et al. 2003). Despite their importance in the food web, feeding preferences of polar, and especially Arctic, amphipods are not well known.
Traditional methods such as in situ observations, gut content analyses and feeding experiments, have provided some information on short-term feeding behavior (Sainte-Marie 1986, 1987, Dauby et al. 2001, Legeżyńska 2001，2008). Recently, techniques such as fatty acid composition and stable isotope analyses have broadened our understanding, integrating feeding patterns over a longer period. Fatty acid composition can be utilized to trace certain fatty acid trophic markers (FATM) that are specific for certain groups (reviewed by Dalsgaard et al. 2003), while the ratios of stable carbon $\left(\delta^{13} \mathrm{C}\right)$ and stable nitrogen $\left(\delta^{15} \mathrm{~N}\right)$ can be used to trace the organisms' major carbon sources and to estimate their TL, respectively (Hobson \& Welch 1992, Søreide et al. 2006a). These methods have provided new information on feeding patterns and trophic structure of Antarctic amphipods (Graeve et al. 2001, Nyssen et al. 2005), but our knowledge about feeding patterns in Arctic amphipod assemblages is still restricted. By studying the feeding preferences of different scavenging amphipods, we wanted to increase understanding of the Arctic food web structure and the ecological significance of amphipods. Further, our aim was to investigate how the amphipods' feeding behavior affects their attraction to bait.

We studied the amphipod scavenging guild in 2 contrasting Arctic fjords in Svalbard, Norway: Adventfjorden and Rijpfjorden, differing both in hydrology and climate (Zajączkowski et al. 2010, Ambrose et al. 2006, Berge et al. 2009). As the conditions are different in the 2 fjords, we expected a different set of scavenging amphipods in each fjord, but a similar seasonality in catch sizes. Our hypothesis was that the seasonal variation in species composition is relatively low and that the co-existence of several amphipod species is possible due to these species' opportunistic feeding strategies and high flexibility in diet, which is influenced by amphipod size, habitat and season.

\section{MATERIALS AND METHODS}

\section{Study area}

Sampling was performed in Adventfjorden $\left(78^{\circ}\right.$ $\left.13.5^{\prime} \mathrm{N}, \quad 15^{\circ} 40.5^{\prime} \mathrm{E}\right)$ and Rijpfjorden $\left(80^{\circ} 13.3^{\prime} \mathrm{N}\right.$, $22^{\circ} 26.0^{\prime} \mathrm{E}$ ), both fjords located in the Svalbard archipelago, Norway (Fig. 1). In addition, some samples of the sympagic species for lipid and fatty acid analyses were collected in the pack ice north of Svalbard $\left(81^{\circ} 05^{\prime} \mathrm{N}, 14^{\circ} 54^{\prime} \mathrm{E}\right)$. 


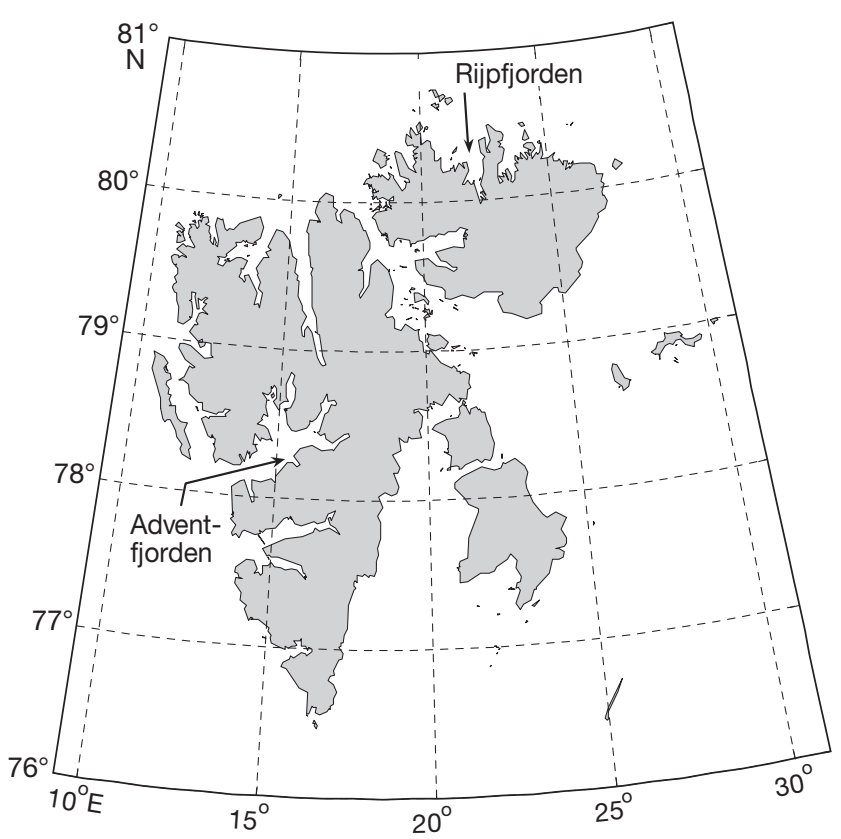

Fig. 1. Svalbard archipelago, Norway, showing the study fjords, Adventfjorden and Rijpfjorden

Adventfjorden is a branch of the Isfjorden system on the western side of Spitsbergen. Isfjorden is influenced by the West Spitsbergen Current that brings warm Atlantic water into the fjord and creates a rather mild climate in the area (Svendsen et al. 2002). The temperature in Adventfjorden varies at $30 \mathrm{~m}$ depth from around $-1^{\circ} \mathrm{C}$ in April to around $5^{\circ} \mathrm{C}$ in July (Zajączkowski et al. 2010). No sea ice formed during our study period 2006 to 2007. Adventfjorden is influenced by 2 rivers, Adventelva and Longyearelva, which transport melt water from glaciers located several kilometers inland from the shore. The surface salinity in the fjord decreases to less than 5 psu during the approximately $120 \mathrm{~d}$ long melting period during summer (Zajączkowski et al. 2010, Wesławski et al. 1999). The rivers also bring a lot of suspended terrigenous particles, increasing the turbidity in the water during the melt period. The sedimentation rate of inorganic particles is 60 to $80 \mathrm{~g} \mathrm{~m}^{-2}$ $\mathrm{d}^{-1}$ (Zajączkowski et al. 2010) and as a result the bottom in the fjord consists mainly of silt (Pawłowska et al. 2011). In the outer part of Adventfjorden the sedimentation rate of suspended particles is reduced and the sediment is coarser (Zajączkowski 2008).

Rijpfjorden is a north-facing fjord located on Nordaustlandet and is characterized by Arctic surface water (Ambrose et al. 2006, Berge et al. 2009). The fjord is ice-covered 6 to 8 mo per year (Wallace et al. 2010). In 2007, ice formed in early February and the ice cover started to break up in the end of June and had totally disappeared by mid-July (Søreide et al. 2010). The hydrography in the fjord was monitored continuously from August 2006 to August 2008 by a mooring (Wallace et al. 2010). During the period when the fjord was ice-covered, the water column had a homogenous temperature of around $-1.8^{\circ} \mathrm{C}_{i}$ in the open period the surface layer warmed up to $4^{\circ} \mathrm{C}$, while the bottom water remained cold (Søreide et al. 2010). Although one large glacier feeds the fjord with melt water, the influence of melt water in the sampling area is comparatively small. The bottom substrate in the sample area consisted mainly of gravel, in contrast to the soft sediments in Adventfjorden.

\section{Sampling}

Sampling was performed using baited traps with similar-sized pieces of chicken meat as bait packed in a fine mesh bag, preventing the animals from feeding on the bait (Nygård et al. 2009). In both fjords, 3 transects with 5 traps each were regularly deployed. The transects started close to shore at depths of around 1 to $2 \mathrm{~m}$ and extended outwards with $50 \mathrm{~m}$ between the traps, typically ending at a depth of 20 to $40 \mathrm{~m}$. The traps were deployed for approximately $24 \mathrm{~h}$ at a time. In Adventfjorden sampling was carried out regularly from September 2006 until August 2007, in Rijpfjorden from February to October 2007 with an additional sampling campaign in April 2008 (for sampling dates see Tables S1 and S2 in the supplement at www.int-res.com/articles/ suppl/b014p247_supp.pdf). In Rijpfjorden samples were also taken from deeper parts of the fjord (maximum depth $180 \mathrm{~m}$ ) and from traps mounted directly under the sea ice (hereafter called 'ice traps'). The ice traps were used in both shallow $(<40 \mathrm{~m})$ and deep (>40 m) areas in Rijpfjorden.

The samples were sorted under a stereomicroscope and identified to species level/nearest taxa. Anonyx species were determined according to the key in Steele \& Brunel (1968), and Onisimus species according to Vader et al. (2005) and Berge et al. (2007). In addition, the length of the first pereonal segment (Ls), which can be used as a trustworthy proxy for total length (Arndt and Beuchel 2006, Nygård et al. 2009), was measured on the Onisimus species for life cycle estimation. Length measurements on $O$. brevicaudatus were made with 2 different stereomicroscopes that, unfortunately, did not have the same magnification; resulting in uneven measurement intervals. Replicate samples of each species were taken for lipid and stable isotope analyses each 
month except for the June, July and October samples of O. glacialis (see Tables 4 and S4). Samples were packed in aluminum foil and shock-frozen in liquid nitrogen immediately after collection and then stored at $-80^{\circ} \mathrm{C}$ until further analysis.

\section{Lipid and fatty acid analyses}

Wet and dry weight (DW), lipid class and fatty acid composition were determined for Anonyx nugax, Onisimus glacialis, $O$. nanseni, $O$. litoralis and $O$. caricus. Fatty alcohols were also analyzed for the wax ester-rich species $O$. glacialis, $O$. nanseni and $O$. litoralis. For A. nugax, all lipid samples were from Rijpfjorden, except for February when samples from Adventfjorden were used. Samples of $O$. glacialis and $O$. nanseni were collected in Rijpfjorden and additionally in September from the pack ice north of Svalbard. All O. litoralis and $O$. caricus specimens for lipid and stable isotope analyses were collected in Adventfjorden. A sample consisted of a single individual, except for $O$. glacialis where 2 individuals were pooled in order to get enough material for the analyses. Samples for lipid class and fatty acid data for A. nugax were collected from the fast ice in Rijpfjorden in April $2007(\mathrm{n}=4)$ and $2008(\mathrm{n}=3)$. A $t$-test did not reveal differences in any lipid class or fatty acid between the years and hence these samples were pooled.

Lipid classes, fatty acids and fatty alcohols were analyzed at UNILAB, Tromsø, Norway. Prior to analysis, the samples were wet weighed and freeze-dried to obtain the DW. The dried samples were homogenized in chloroform:methanol 2:1 (v/v), and total lipid was extracted, following Folch et al. (1957), and weighed.

Sub-samples of the total lipid extract were used to analyze the lipid class and fatty acid composition of the polar and neutral lipid fraction, separated using solid bond extraction-fractionation as described by Kaluzny et al. (1985). A known amount of the fatty acid 21:0 was added as an internal standard to both fractions and an acid-catalyzed transesterification was carried out with $1 \%$ sulphuric acid in methanol (Christie 1982). The relative (\%) compositions of fatty acid methyl esters and fatty alcohol acetates were determined on an Agilent $6890 \mathrm{~N}$ gas chromatograph, equipped with a fused silica, wall-coated capillary column with an Agilent 7683 injector and flame ionization detection. Hydrogen was used as the carrier gas with an oven thermal gradient from an initial 60 to $150^{\circ} \mathrm{C}$ at $30^{\circ} \mathrm{C} \mathrm{min}^{-1}$, and then to a final temperature of $230^{\circ} \mathrm{C}$ at $1.5^{\circ} \mathrm{C} \mathrm{min}^{-1}$. Individual components were identified by comparing them to known stan- dards and were quantified using HPChemStation software (Hewlett-Packard).

The presence of 20:1 and 22:1 fatty acids and fatty alcohols are used as FATM for feeding on calanoid copepods (Sargent \& Falk-Petersen 1988), while the sum of C16 polyunsaturated fatty acids, $16: 1 \mathrm{n}-7$ and 20:5 n-3 fatty acids are used as an indicator for diatom feeding (Dalsgaard et al. 2003). A high ratio of $18: 1 \mathrm{n}-9 / \mathrm{n}-7$ is used as an indicator of carnivory and necrophagy (Sargent \& Falk-Petersen 1981, Bühring \& Christiansen 2001).

\section{Stable isotope analysis}

Stable carbon and nitrogen isotope analyses were performed at the Institute for Energy Technology, Kjeller, Norway as described in Søreide et al. (2006b), which includes removal of both inorganic carbon and lipids before analyses. All samples consisted of a single amphipod individual.

TL was calculated by using a stepwise enrichment factor of $3.4 \%$ o $\delta^{15} \mathrm{~N}$ per level (Søreide et al. 2006a) and setting the baseline level $(\mathrm{TL}=1)$ at $\delta^{15} \mathrm{~N}=3.6 \%$ during the ice-covered season (April-June) in Rijpfjorden (mean value for ice algae in Rijpfjorden April 2007; Leu et al. 2010), and $\delta^{15} \mathrm{~N}=4.0 \%$ (mean value for phytoplankton in Svalbard waters; Søreide et al. 2006a) during the open water season (July-October) in both for Rijpfjorden and for all samples from Adventfjorden.

\section{Statistical analyses}

The trap samples were divided into depth zones $(0-5,5-20,20-40,40-100$ and $>100 \mathrm{~m})$ and a catch per unit effort (CPUE) value was calculated separately for each depth zone and month. The catch was expressed as the number of individuals and 1 trap deployed for $24 \mathrm{~h}$ was taken as 1 unit of effort.

Constrained correspondence analysis (CCA) was used to obtain a graphical representation of the depth and fjord allocation of amphipod species. CCA is a $\chi^{2}$ distance-based ordination method, where a community data matrix is constrained by a matrix of explanatory variables (ter Braak 1986). Fjord and the depth zone data (pooling the $40-100 \mathrm{~m}$ and $>100 \mathrm{~m}$ depth zones) was used as the explanatory matrix. CPUE data for each trap was $\log (x+1)$ transformed and entered into the community data matrix. Empty traps and Ischyrocerus anguipes (only 1 specimen was found) were removed from the dataset. The 
analysis was performed using R-statistical environment (R Development Core Team 2010) and Vegan (Oksanen 2011). Depth contour was fitted to the CCA model using a generalized additive model (GAM, 'ordisurf' command in Vegan). In addition, samples were tested for difference between fjords, depth zones and months using the PERMANOVA+ package (Anderson et al. 2008) for PRIMER v6 (Clarke \& Gorley 2006). The PERMANOVA analysis uses the Bray-Curtis similarity index and performs a permutation test to judge the similarities between chosen factors. For calculating the Bray-Curtis similarity index the data was square-root transformed and a dummy variable of 0.0001 was added. This was necessary to include the variability of using baited traps for sampling, as many traps were empty. Factors used in the PERMANOVA analysis were fjord, depth zone and month. In cases where the number of unique permutations was $<100$ the Monte Carlo p-value was chosen (Anderson et al. 2008). The significance level was set to 0.05. For the pairwise PERMANOVA tests a Holm-Bonferroni correction for multiple comparisons was applied (Holm 1979), thus lowering the critical significance level. PRIMER was also used for calculating Shannon-Wiener's diversity index and Pielou's evenness index (Clarke 1993).

A principal component analysis (PCA) was performed using CANOCO for Windows v4.5 to investigate the dominant patterns in the fatty acid composition among species (ter Braak \& Smilauer 2002). Only fatty acids contributing more than $1 \%$ were included in the analysis and the compositional data was not transformed prior to analysis. Ordination techniques and rules of interpretation of PCA ordination plots are summarized by ter Braak (1995) and ter Braak \& Smilauer (2002). In short, the closer the samples are clustered together the more similar fatty acid composition they have. The fatty acids (shown as arrows) are standardized and centered and point in the direction of maximum change. Projecting samples perpendicularly to the arrows indicates their relative amount of these fatty acids. The angle between arrows indicates their correlation, i.e. they are uncorrelated if they are perpendicular to each other and highly correlated (positive or negative) if the angle is small. The lengths of the arrows indicate the importance of the fatty acid in describing the variability.

The lengths-frequencies of Onisimus edwardsii and $O$. brevicaudatus were plotted in R-statistical environment ( $R$ Development Core Team 2010). Kernel densities were obtained using the default values in the 'density' function, except for band-width, which was set to 0.04 .

\section{RESULTS}

\section{Species composition}

A total of 8 amphipod species (in addition to the decapod Eualus gaimardii in September) were collected in the samples from Adventfjorden, whereas 19 amphipod species were recorded in Rijpfjorden (see Tables S1 and S2 in the supplement at www.intres.com/articles/suppl/b014p247_supp.pdf). The average (mean $\pm \mathrm{SD}$ ) species richness in the samples was $3.8 \pm 1.7$ in Adventfjorden and $5.1 \pm 2.2$ in Rijpfjorden $(t=0.012)$. In terms of diversity, a lower ShannonWiener index (mean $\pm \mathrm{SD}$ ) was observed in Adventfjorden, $0.57 \pm 0.42$, compared to $1.06 \pm 0.40$ in Rijpfjorden $(t<0.001)$. Pielou's evenness index (mean $\pm \mathrm{SD}$ ) showed a stronger dominance of few species in Adventfjorden $(0.46 \pm 0.29)$, while a more even distribution of species was observed in Rijpfjorden $(0.68 \pm 0.18, t=0.002)$.

The CCA plot shows clear differences in the species composition of the amphipod scavenging guild between the fjords and among depth layers (Fig. 2). Axis 1 mainly explains the differences in species distribution between the fjords, indicating the importance of Onisimus caricus in Adventfjorden and showing a higher diversity in the scavenging guild in Rijpfjorden. Axis 2 demonstrates the depth zonation in species distribution. Depth contours, fitted to the CCA model (estimated degrees of freedom $=5.85$, generalized cross validation score $=1.30$ ), assist the interpretation of the species' depth preferences (Fig. 2).

Similarly, based on the Bray-Curtis similarity index, the species composition in the baited trap samples was significantly different between the 2 studied fjords (PERMANOVA: pseudo- $F=48.186 ; \mathrm{p}<0.001$ ) and among the depth zones (PERMANOVA: pseudo$F=9.911$ and 4.957 for Adventfjorden and Rijpfjorden, respectively; $\mathrm{p}<0.001$ ). In Adventfjorden the 0-5 $\mathrm{m}$ depth zone was significantly different from both the 5-20 and 20-40 m depth zones $(t=3.536$ and 3.701, respectively; $\mathrm{p}<0.001$ ), whereas the species composition was similar in the 5-20 and 20-40 m depth layers. In Rijpfjorden the depth layers deeper than $20 \mathrm{~m}$ showed similarities, whereas the 2 shallower depth zones differed significantly from each other and the deeper layers. Moreover, a difference in species composition between months was observed both in Adventfjorden and in Rijpfjorden (PERMANOVA: pseudo- $F=3.329$ and 7.591, respectively; $\mathrm{p}<0.001$ ). In Adventfjorden, the species composition observed in the 5-20 m depth layer, in the spring months April and May, differed from that found in the 


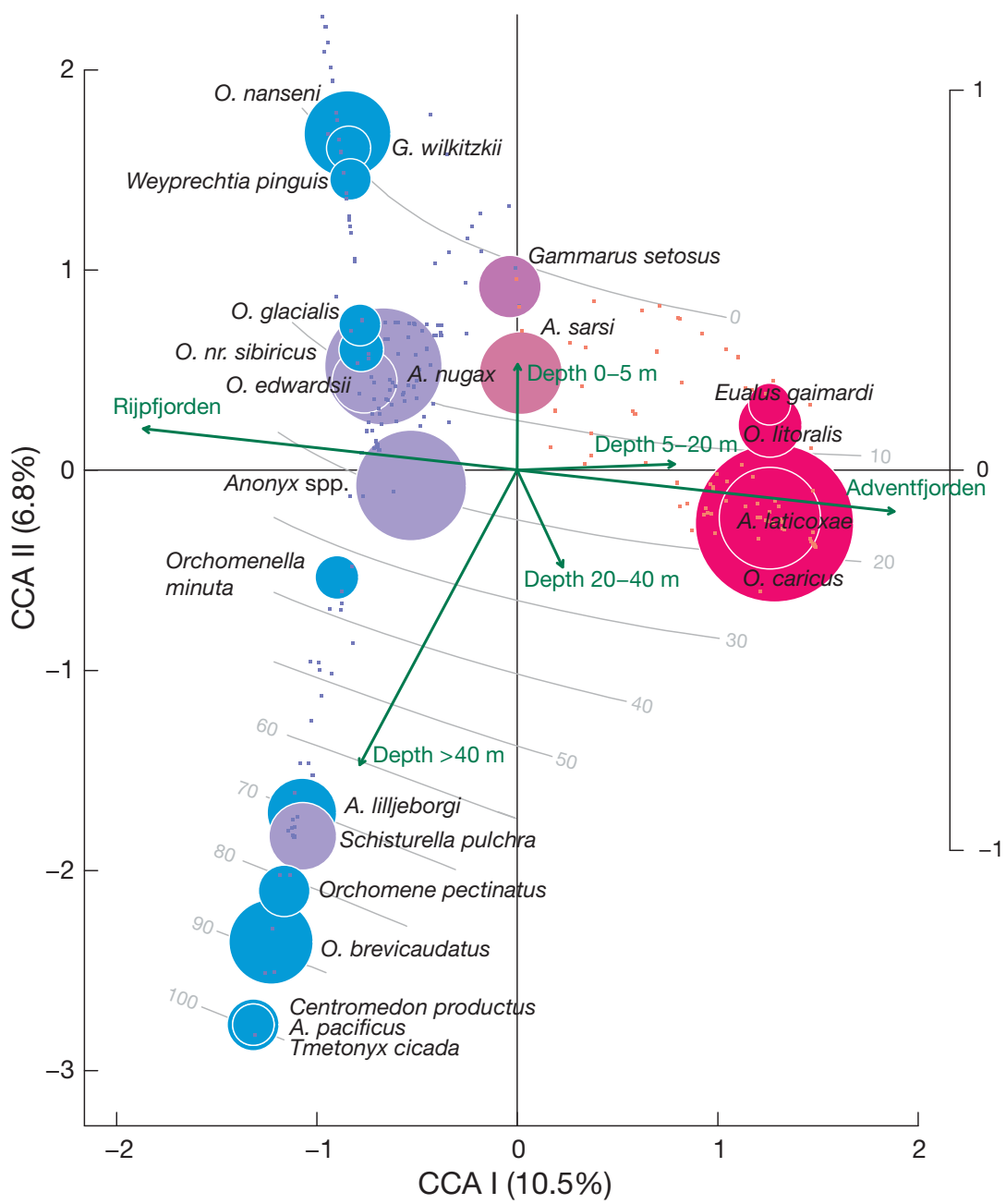

Fig. 2. Constrained correspondence analysis (CCA) plot illustrating the distribution of amphipod species in baited trap samples collected from Adventfjorden and Rijpfjorden in the Svalbard archipelago. Each species is represented by a filled circle whose diameter corresponds to the mean catch per unit effort (CPUE) of the species. Red and blue circles indicate species collected in Adventfjorden and Rijpfjorden respectively. Shades of purple indicate that the species were encountered in both fjords. Shades closer to red indicate higher occurrence in Adventfjorden, while shades closer to blue indicate higher occurrence in Rijpfjorden. The arrows indicate the explanatory variables. Small red and blue dots represent the samples collected in Adventfjorden and Rijpfjorden, respectively. Axis 1 mainly explains the distribution between fjords, whereas Axis 2 mainly explains the depth distribution of the species. Fitted depth contours are plotted in grey

late autumn months October and November (Table 1). In Rijpfjorden, species composition in the June and July samples was different than in other months (Table 1). In February, the species composition in the 20-40 m depth layer significantly differed from that in March and April at the same depth (Table 1).

In Adventfjorden, the most common species in the traps was Onisimus caricus (Table S1). Except in September, it was by far the most abundant species. It was present in all depth layers with highest abundance at depths deeper than $5 \mathrm{~m}$. O. litoralis and Gammarus setosus were frequently found in the shallowest traps $(0-5 \mathrm{~m})$. In Adventfjorden, 3 species of Anonyx were recorded, the most common being $A$. laticoxae. This species occurred in all depth layers, but it was more abundant in the deeper ones. A. sarsi occurred mostly in the shallowest traps, while $A$. nugax was mainly found deeper. Compared to the high number of juvenile Anonyx spp. recorded in Rijpfjorden, very few were found in Adventfjorden. In September, when the traps where placed at a slightly different place, A. laticoxae was the most abundant species recorded. O. edwardsii and the decapod Eualus gaimardii were only found in September.

In Rijpfjorden, the scavenging amphipod fauna was heavily dominated by Anonyx species (Table S2). A. nugax and Anonyx spp. juveniles were abundant in all depth layers, except in June and July when the overall catches were small. Other Anonyx species recorded in Rijpfjorden were $A$. sarsi in the shallow traps, A. lilljeborgi in the deeper traps, as well as $A$. laticoxae and $A$. pacificus that were only infrequently recorded. Five species of Onisimus were recorded in Rijpfjorden. O. brevicaudatus was almost only present in the deep traps, and sometimes in high numbers (>900 ind. in one trap), while $O$. edwardsii and $O$. nr. sibiricus (see Berge et al. 2007) were only present in the shallower traps. In addition, a few specimens of the sympagic species $O$. nanseni and $O$. glacialis were caught in the traps on the bottom. $O$. nanseni was recorded in traps at 20-40 m depth in March and April, while O. glacialis was caught in the traps at 5-20 m depth in April. In July both these sympagic species were collected close to shore at 
Table 1. Significant $t$-values and p-values from the pairwise PERMANOVA test of differences in species composition of amphipods in 2 Arctic fjords between months and depth layers. Following a Holm-Bonferroni correction for multiple comparisons the critical significance level was set to 0.0012 in Adventfjorden and to 0.0033 (depths 0-5 and 5-20 m) and 0.0050 (20-40 m) in Rijpfjorden

\begin{tabular}{|lccr|}
\hline Tested months & Depth $(\mathrm{m})$ & $t$ & $\mathrm{p}$ \\
\hline Adventfjorden & & & \\
October, April & $5-20$ & 3.773 & $<0.001$ \\
October, May & $5-20$ & 2.796 & $<0.001$ \\
November, April & $5-20$ & 3.440 & $<0.001$ \\
November, May & $5-20$ & 2.683 & 0.001 \\
Rijpfjorden & & & \\
February, March & $20-40$ & 1.971 & 0.004 \\
February, April & $20-40$ & 2.216 & 0.003 \\
February, June & $5-20$ & 2.844 & $<0.001$ \\
February, June & $20-40$ & 3.527 & $0.002^{\mathrm{a}}$ \\
February, July & $0-5$ & 2.555 & $<0.001$ \\
February, July & $5-20$ & 2.810 & $<0.001$ \\
March, June & $0-5$ & 3.038 & $0.002^{\mathrm{a}}$ \\
March, June & $5-20$ & 2.523 & 0.002 \\
March, July & $0-5$ & 2.132 & 0.003 \\
March, July & $5-20$ & 2.647 & $<0.001$ \\
April, June & $20-40$ & 1.826 & 0.002 \\
April, July & $0-5$ & 1.997 & 0.001 \\
April, July & $5-20$ & 2.575 & $<0.001$ \\
June, July & $0-5$ & 3.489 & $<0.001$ \\
July, October & $0-5$ & 2.383 & $<0.001$ \\
July, October & $5-20$ & 2.671 & $<0.001$ \\
andicates Monte-Carlo p-values & & \\
& & & \\
\hline
\end{tabular}

depths of 0-5 m. Orchomenella minuta was frequently recorded in low numbers in Rijpfjorden in all depth layers, while Orchomene pectinatus, Schisturella pulchra and Centromedon productus were mostly recorded in the deeper traps. Gammarus setosus was also frequently found in the shallowest traps.

In the ice traps attached directly under the sea ice in Rijpfjorden, a total of 8 species were recorded, all of which have been previously recorded in the sea ice habitat (e.g. Melnikov \& Kulikov 1980). The ice traps placed in shallow waters contained primarily benthic species such as Gammarus setosus, Ischyrocerus anguipes, Weyprechtia pinguis and Anonyx spp. (Table S3). The sympagic species Onisimus Nanseni, $O$. glacialis and $G$. wilkitzkii were mainly found under the ice over deep water. Of these, $O$. nanseni showed a highly patchy distribution. In April 2007 almost all $O$. nanseni were collected in a small area below sea ice, where the water depth was $180 \mathrm{~m}$, with >200 ind. per trap, while in other areas on deep water most of the ice traps were completely empty. In April 2008 the most abundant species in the ice traps was A. nugax. This species was regularly present in the ice traps, whereas only a few individuals of the sympagic am- phipods were collected. In total 908 ind. of A. nugax were caught in the ice traps in April 2008, of which 227 random ind. were sexed: 158 (70\%) were mature males, $13(6 \%)$ were immature males, $53(23 \%)$ were immature females and $3(1 \%)$ were juveniles.

In general, more amphipods were caught in the winter months compared to the summer months (Fig. 3). In Adventfjorden, the peak in catch size was in November, after which the catch size decreased continuously through the winter. In April, almost no amphipods were caught shallower than $20 \mathrm{~m}$, and in May very few amphipods were caught in total. In June the catch size increased again, mainly at depths $>5 \mathrm{~m}$ (Table S1). In Rijpfjorden, the mean CPUE was highest in February, after which the catch size decreased during spring. In June and July CPUE was very low compared to the rest of the year. The large number of juvenile Anonyx spp. in the traps in September indicate that recruitment to the population had occurred. In October, the shallowest traps caught a very low number of amphipods, probably due to a storm creating wave action and thus disturbing the shallow sampling (Table S2).

\section{Length-frequency distribution of Onisimus edwardsii and $O$. brevicaudatus}

New data on length-frequency distributions are only presented for Onisimus edwardsii and O. brevicaudatus in this study. For the more numerous species the length frequency has been described elsewhere (Boudrias \& Carey 1988, Węsławski et al. 2000, Arndt \& Beuchel 2006, Nygård et al. 2009, 2010) and will be referred to in the discussion.

The smallest individuals of Onisimus edwardsii were recorded in February and March and measured $0.25 \mathrm{~mm}$ (Ls). The largest individuals were observed in both February and April and measured $0.98 \mathrm{~mm}$ (Ls) (Fig. 4). Based on the length-frequency distribution and kernel densities, the occurrence of 3 separate cohorts seems likely, which suggests that $O$. edwardsii has a 2 yr life cycle.

Onisimus brevicaudatus was almost exclusively recorded in the deep traps and the only month with sufficient length data was April (Fig. 5). The smallest individuals measured $0.25 \mathrm{~mm}$ (Ls), while the largest individuals measured $1.11 \mathrm{~mm}$ (Ls). Based on the length-frequency distribution and kernel densities, 3 cohorts seem likely, assuming that the smallest individuals, despite few observations, formed a separate cohort. This suggests that $O$. brevicaudatus also has a 2 yr life cycle. 


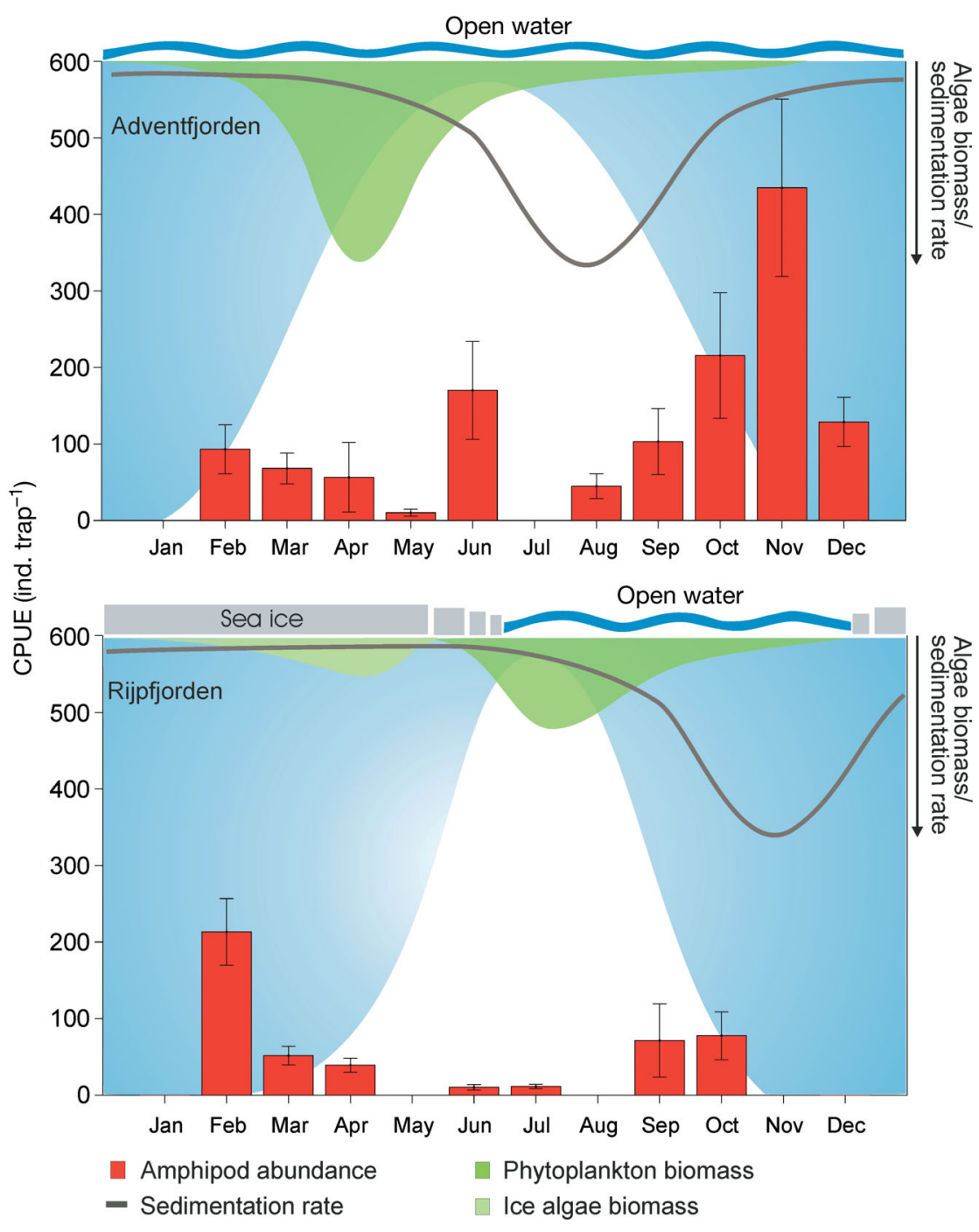

Fig. 3. Seasonal variation in amphipod trap catches in different depth zones in Adventfjorden and Rijpfjorden. Error bars indicate standard error. Note that amphipod abundances in September to December in Adventfjorden are from 2006, while all other data is from 2007. Data on phytoplankton and sedimentation rates in Adventfjorden are based on Zajączkowski et al. 2010, while ice algae and phytoplankton curves in Rijpfjorden are based on Søreide et al. 2010. The sedimentation rate for Rijpfjorden is based on data from sediment traps placed at $100 \mathrm{~m}$ depth on a mooring (J. Berge et al. unpubl.) and is thus not directly comparable to sedimentation rates shown for Adventfjorden. The white areas represent incoming light

\section{Total lipid and lipid classes}

The highest lipid contents were found in Onisimus glacialis, $O$. nanseni and O. litoralis (Table 2). In these species the lipid content was generally between 15 and $30 \%$ of DW, with the highest values observed in summer and autumn. In Anonyx nugax, the lipid content of samples collected from the bottom was between 11 and $19 \%$ of DW, compared to only 6 to $9 \%$ of DW in samples from the ice traps. $O$. caricus had low lipid content compared to the other Onisimus species (Table 2).

In all species, triacylglycerols made up the largest proportion of the lipids (Table 2). Wax esters were important in Onisimus nanseni, especially during the spring when $>40 \%$ of total lipids were wax esters. Wax esters were also important in O. glacialis, while this lipid class seems to be of minor importance
$(<15 \%)$ for the other studied species. The remaining lipids were to a large extent phospholipids.

\section{Fatty acid composition}

More than $70 \%$ of the total fatty acid variability is shown in the 2-dimensional PCA plot, suggesting strong and consistent patterns in fatty acid composition in the 94 samples comprising 5 different amphipod species (Fig. 6). The strongest gradient, Axis 1, explains close to $50 \%$ of the total fatty acid variability and shows a gradient from mainly herbivorousomnivorous to carnivorous, as indicated by the change from elevated levels of the typical algae FATMs 20:5 n-3, and C16 and C18 polyunsaturated fatty acids, to elevated levels of the typical carnivore FATM 18:1 n-9 (Fig. 6). The second gradient, Axis 2, 
mainly shows a gradual change from typical diatom FATMs to typical calanoid copepod FATMs (i.e. 20:1 and 22:1).

Based on the 5 species' fatty acid composition, Onisimus glacialis and $O$. litoralis were those with the most herbivorous diet (Fig. 6, Table S4). The 3 other species were predominantly carnivorous during all seasons with $O$. nanseni and Anonyx nugax seasonally having high proportions of Calanus FATMs (up to 37 and $30 \%$, respectively; Table S4). O. caricus had a particularly high proportion of the carnivore FATM 18:1 n-9 (30-48\%).

In Anonyx nugax, the level of 18:1 n-9 was elevated during winter, while the lowest values for this fatty acid were observed in the ice traps in spring. Onisimus litoralis also showed seasonal variation in this carnivorous FATM, with the lowest values recorded in summer (overall mean $13.7 \%$ ). O. glacialis had consistently low proportions of 18:1 n-9 (overall mean, spring to autumn, $14.2 \%$; winter values not available).

The calanoid copepod FATMs, 20:1 and 22:1, were particularly important in Onisimus nanseni, where the sum of these fatty acids comprised almost $35 \%$ during spring (Table S4). In Anonyx nugax these fatty acids were elevated in April, and again in August to September. $O$. glacialis had moderate levels of 20:1 and 22:1 fatty acids (max. $18.5 \%$ in October), whereas these fatty acids were of little importance for O. litoralis (mean $8.2 \%$ ) and O. caricus (mean $3.9 \%$ ). Levels of $20: 1$ and 22:1 fatty alcohols were high in $O$. nanseni and considerable in O. glacialis (Table 3).

The diatom FATMs 16:1 n-7 and 20:5 n-3 were particularly important in Onisimus glacialis and $O$. litoralis, with the highest values recorded in summer. Other important fatty acids were 16:0 (in all studied species), and 22:6 n-3 (especially in Anonyx nugax).

\section{Stable isotopes}

Based on $\delta^{13} \mathrm{C}$ and $\delta^{15} \mathrm{~N}$ values no clear seasonal pattern in trophic position could be seen for Anonyx nugax (Table 4). The trophic position of this species seemed to be stable at a high TL (3.3-3.5) throughout the year. Onisimus caricus had a trophic position between 2.9 and 3.3, whereas $O$. nanseni (2.6-2.9) and $O$. litoralis $(1.8-2.8)$ had the lowest trophic positions, with particularly low values in July (Table 4).
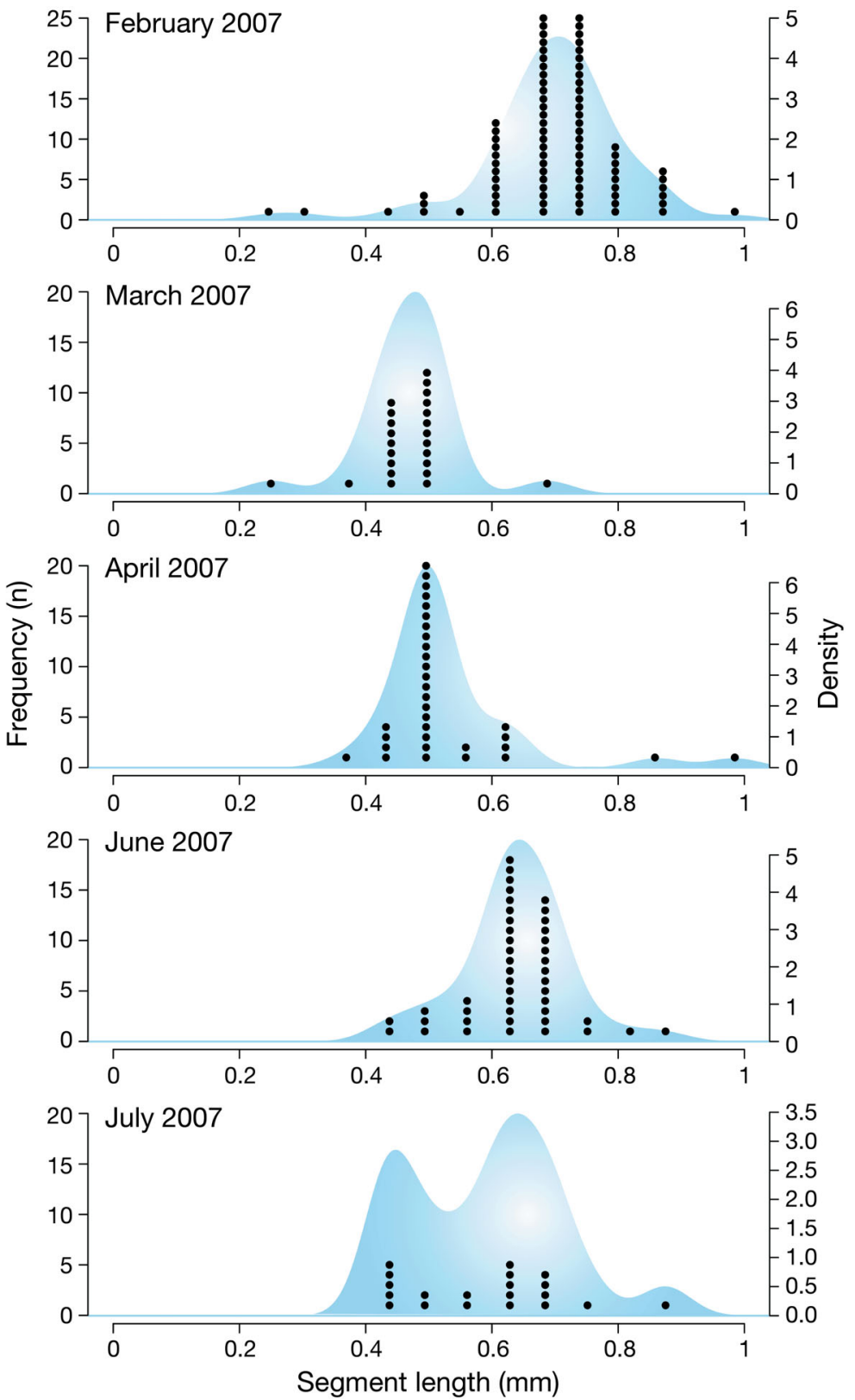

Fig. 4. Onisimus edwardsii. Length-frequency distribution (black dots; $\mathrm{n}=$ no. of individuals) and kernel density distribution (blue background) in samples collected in Rijpfjorden in April 2007

\section{DISCUSSION}

\section{The amphipod scavenging guild}

There was a clear difference in the species composition between the 2 fjords, which was as expected, given their differing environmental conditions. As seems to be common in Arctic coastal waters (Sainte-Marie 1986, Legeżyńska et al. 2000), the 2 genera Anonyx and Onisimus co-occured and 


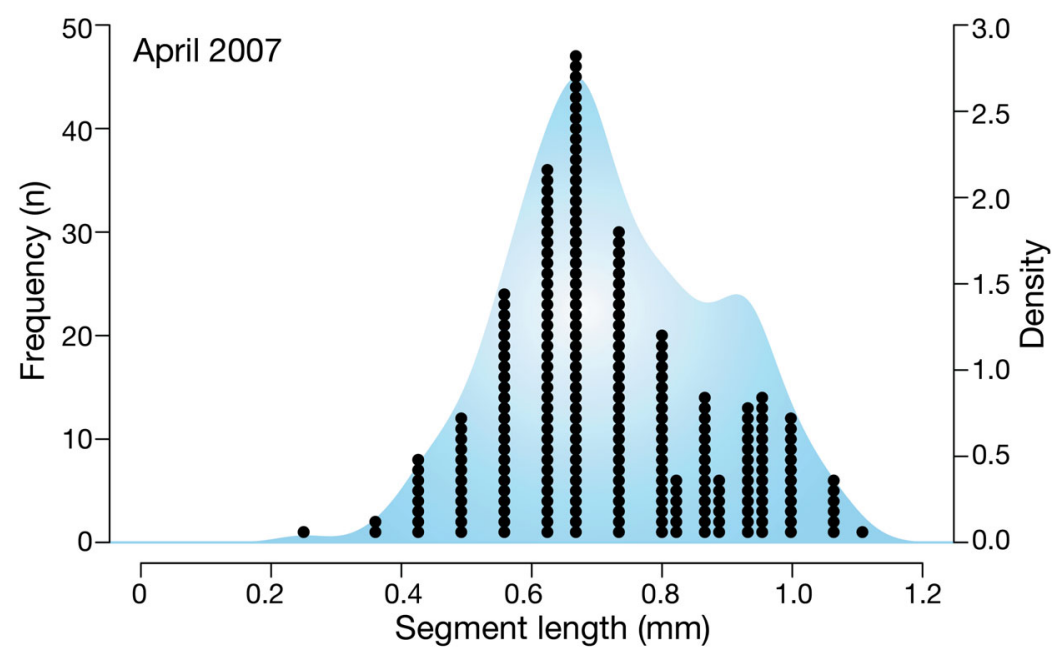

Fig. 5. Onisimus brevicaudatus. Length-frequency distribution (black dots; $\mathrm{n}=$ number of individuals) and kernel density distribution (blue background) in samples collected in Rijpfjorden in April 2007 dominated the scavenging guild also in our study. However, different sets of species from these genera were found in the 2 fjords, with different species showing different habitat preferences.

The high-Arctic Rijpfjorden opens directly towards the Arctic Ocean with drifting sea ice influencing the fjord environment (Hop \& Pavlova 2008). The presence of the true ice fauna Onisimus nanseni, O. glacialis and Gammarus wilkitzkii in Rijpfjorden underlines the strong influence of pack ice from the Arctic Ocean; none was detected in the more Atlantic influenced fjords on Svalbard, such as Adventfjorden (this study) or Kongsfjorden (Legeżyńska 2001). In both Adventfjorden and Rijpfjorden, the

Table 2. Wet weight (WW), dry weight (DW), total lipid content and lipid classes of lysianassoid amphipods in Adventfjorden and Rijpfjorden. See 'Materials and methods' for details of sampling locations. WE: wax esters; TAG: triacylglycerol; C: cholesterol; DAG: diacylglycerol; MAG: monoacylglycerol; GAL: galactocerebrosid; CL: cardiolipin; PL: phospholipids. Dashes indicate no data

\begin{tabular}{|c|c|c|c|c|c|c|c|c|c|c|c|c|}
\hline & & \multirow{2}{*}{$\begin{array}{l}\text { WW } \\
(\mathrm{mg})\end{array}$} & \multirow{2}{*}{$\begin{array}{l}\text { DW } \\
(\mathrm{mg})\end{array}$} & \multirow{2}{*}{$\begin{array}{l}\text { Lipid content } \\
\text { (\% of DW) }\end{array}$} & \multicolumn{8}{|c|}{ Lipid classes ( $\%$ of total lipid) } \\
\hline & & & & & WE & TAG & C & DAG & MAG & GAL & CL & PL \\
\hline \multirow[t]{8}{*}{ Anonyx nugax } & Feb & 479.7 & - & - & - & - & - & - & - & - & - & - \\
\hline & Mar & 322.2 & _- & - & - & _- & - & _- & - & _- & - & - \\
\hline & Apr & 914.8 & 259.9 & 16.4 & 2.5 & 87.4 & 1.8 & 1.0 & 0.0 & 0.4 & 0.2 & 6.6 \\
\hline & $\mathrm{Apr}^{\mathrm{a}}$ & 1301.6 & 272.7 & 9.1 & 6.2 & 55.5 & 5.3 & 0.2 & 0.0 & 1.9 & 0.1 & 30.9 \\
\hline & Jun $^{\mathrm{a}}$ & 1070.1 & 217.7 & 5.8 & 9.4 & 35.7 & 7.6 & 0.8 & 0.0 & 2.6 & 0.0 & 43.9 \\
\hline & Aug & 2465.9 & 576.5 & 18.6 & 1.7 & 88.4 & 1.7 & 1.1 & 0.0 & 0.5 & 0.3 & 6.2 \\
\hline & Sep & 1333.5 & 352.3 & 17.6 & 11.1 & 76.0 & 1.8 & 0.9 & 0.0 & 0.6 & 0.0 & 9.5 \\
\hline & Oct & 1328.1 & 305.4 & 11.2 & 2.9 & 73.8 & 2.3 & 0.9 & 0.0 & 0.9 & 0.0 & 19.2 \\
\hline \multirow[t]{6}{*}{ Onisimus glacialis } & May $^{a}$ & 15.1 & 4.4 & - & 8.7 & 79.4 & 1.3 & 1.6 & 4.4 & 0.0 & 0.0 & 4.5 \\
\hline & Jun $^{\mathrm{a}}$ & 21.7 & 6.4 & 23.4 & 15.7 & 58.3 & 1.9 & 1.4 & 8.7 & 1.0 & 0.0 & 13.0 \\
\hline & $\mathrm{Jul}^{\mathrm{a}}$ & 22.8 & 6.9 & 29.0 & 26.6 & 59.5 & 1.6 & 1.1 & 5.4 & 0.8 & 0.0 & 4.9 \\
\hline & Aug & 26.8 & 7.4 & 24.9 & 14.1 & 70.4 & 2.0 & 0.3 & 3.2 & 0.3 & 0.0 & 9.6 \\
\hline & Sep $^{b}$ & 34.6 & 9.8 & 18.1 & 6.5 & 80.0 & 1.2 & 1.6 & 3.1 & 0.0 & 0.0 & 7.5 \\
\hline & Oct & 13.8 & 3.7 & 30.4 & 30.5 & 56.1 & 3.5 & 0.0 & 0.0 & 0.0 & 0.0 & 9.8 \\
\hline \multirow[t]{8}{*}{ O. nanseni } & $\mathrm{Apr}^{\mathrm{a}}$ & 60.8 & 20.1 & 29.1 & 43.6 & 46.8 & 1.1 & 2.0 & 2.0 & 0.8 & 0.3 & 3.2 \\
\hline & May $^{a}$ & 49.6 & 16.9 & 19.2 & 40.9 & 49.5 & 1.0 & $\begin{array}{l}2.0 \\
1.7\end{array}$ & $\begin{array}{l}2.0 \\
1.7\end{array}$ & 0.7 & 0.3 & 4.1 \\
\hline & Jun $^{\mathrm{a}}$ & 86.2 & 20.3 & 23.8 & 27.5 & 56.4 & 1.8 & 2.5 & 4.0 & 1.1 & 1.0 & 5.7 \\
\hline & Jul & 90.5 & 23.7 & 26.7 & 12.7 & 75.2 & 1.9 & 1.4 & 2.1 & 0.7 & 0.3 & 5.6 \\
\hline & Aug & 125.2 & 39.6 & 24.2 & 20.0 & 71.3 & 0.9 & 0.9 & 0.0 & 0.3 & 0.0 & 6.6 \\
\hline & Sep & 115.1 & 34.6 & 21.6 & 16.8 & 69.3 & 1.5 & 2.2 & 1.4 & 0.7 & 0.3 & 7.9 \\
\hline & Sep $^{b}$ & 96.7 & 25.0 & 15.7 & 19.8 & 48.1 & 2.9 & 3.2 & 10.4 & 1.3 & 1.2 & 13.1 \\
\hline & Oct & 92.2 & 28.7 & 13.6 & 22.3 & 48.5 & 2.6 & 2.2 & 1.6 & 1.2 & 0.7 & 20.9 \\
\hline \multirow[t]{6}{*}{ O. litoralis } & Apr & 44.2 & 11.4 & - & 14.3 & 49.6 & 4.3 & 1.8 & 6.7 & 3.1 & 0.0 & 20.2 \\
\hline & May & 49.9 & 12.2 & 15.2 & 6.5 & 74.0 & 2.4 & 1.9 & 3.3 & 1.0 & 0.0 & 10.9 \\
\hline & Jun & 52.9 & 13.2 & 19.7 & 7.4 & 77.6 & 1.9 & 2.6 & 1.1 & 1.8 & 0.0 & 7.6 \\
\hline & Jul & 58.7 & 17.5 & 32.2 & 9.3 & 85.4 & 1.2 & 1.2 & 0.0 & 0.0 & 0.0 & 2.8 \\
\hline & Aug & 120.3 & 30.1 & 26.8 & 5.4 & 90.0 & 1.0 & 1.0 & 0.0 & 0.0 & 0.0 & 2.7 \\
\hline & Nov & 126.3 & 21.8 & - & 12.9 & 16.1 & 9.7 & 0.0 & 8.4 & 4.0 & 4.8 & 44.1 \\
\hline \multirow[t]{3}{*}{ O. caricus } & Feb & 272.0 & 70.6 & 5.8 & 3.1 & 60.0 & 3.6 & 3.2 & 4.5 & 1.0 & 0.0 & 24.7 \\
\hline & Jun & 185.5 & 51.8 & 11.7 & 7.8 & 86.8 & 1.3 & 0.0 & 0.0 & 0.0 & 0.0 & 4.1 \\
\hline & Nov & 280.3 & 74.0 & 8.5 & 2.0 & 78.5 & 2.2 & 2.1 & 1.3 & 0.7 & 0.4 & 12.9 \\
\hline
\end{tabular}


Fig. 6. Principal component analysis of the fatty acids contributing $>1 \%$ of the total lipid composition in the studied amphipods, showing 3 distinct groupings. Axis 1, explaining $48 \%$ of the total variability, shows a gradient from herbivory on the left side to carnivory/scavenging on the right side, whereas Axis 2 (explaining $23 \%$ of the total variability) shows a gradient from diatom fatty acid trophic marker (FATM) in the upper part to Calanus FATM in the lower part of the figure. See 'Materials and methods' for further explanation

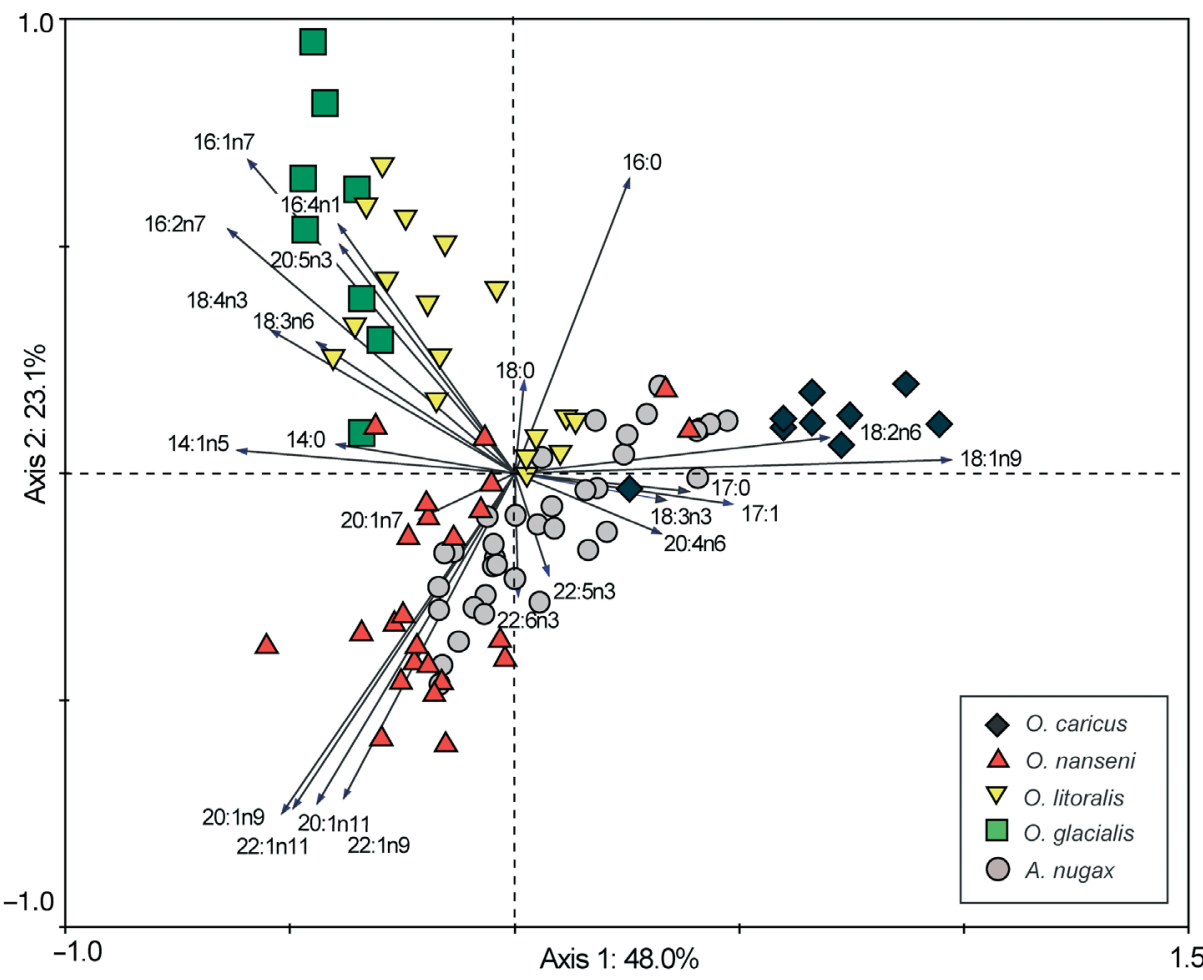

scavenging guild was dominated by typical coldwater species, similar to results from other Arctic areas (Legeżyńska et al. 2000); even though the difference in the temperature regime between the 2 fjords was pronounced, temperature probably had less influence on the species composition than did sea ice. While sympagic fauna drifting out in the Fram Strait is believed to be lost to the pelagial and benthos when the ice melts (Werner et al. 1999,
Arndt \& Pavlova 2005, Hop \& Pavlova 2008), the fate of these species when they are released from ice melting in shallow, seasonally ice-covered areas is not fully understood. There are indications that sympagic amphipods can survive ice-free periods in the benthic habitat and re-colonize the ice when it is reformed (Arndt et al. 2005b, Nygård et al. 2007). Based on ice charts, drift ice was present in Rijpfjorden in autumn 2006 from the end of September to

Table 3. Onisimus nanseni, O. glacialis and $O$. litoralis. Fatty alcohols as percent of total lipid content. n: number of replicate samples. When 3 replicates were measured, results are shown as mean $\pm \mathrm{SD}$, when 2 replicate samples were measured, the range is shown, and when 1 sample was measured the single value is shown

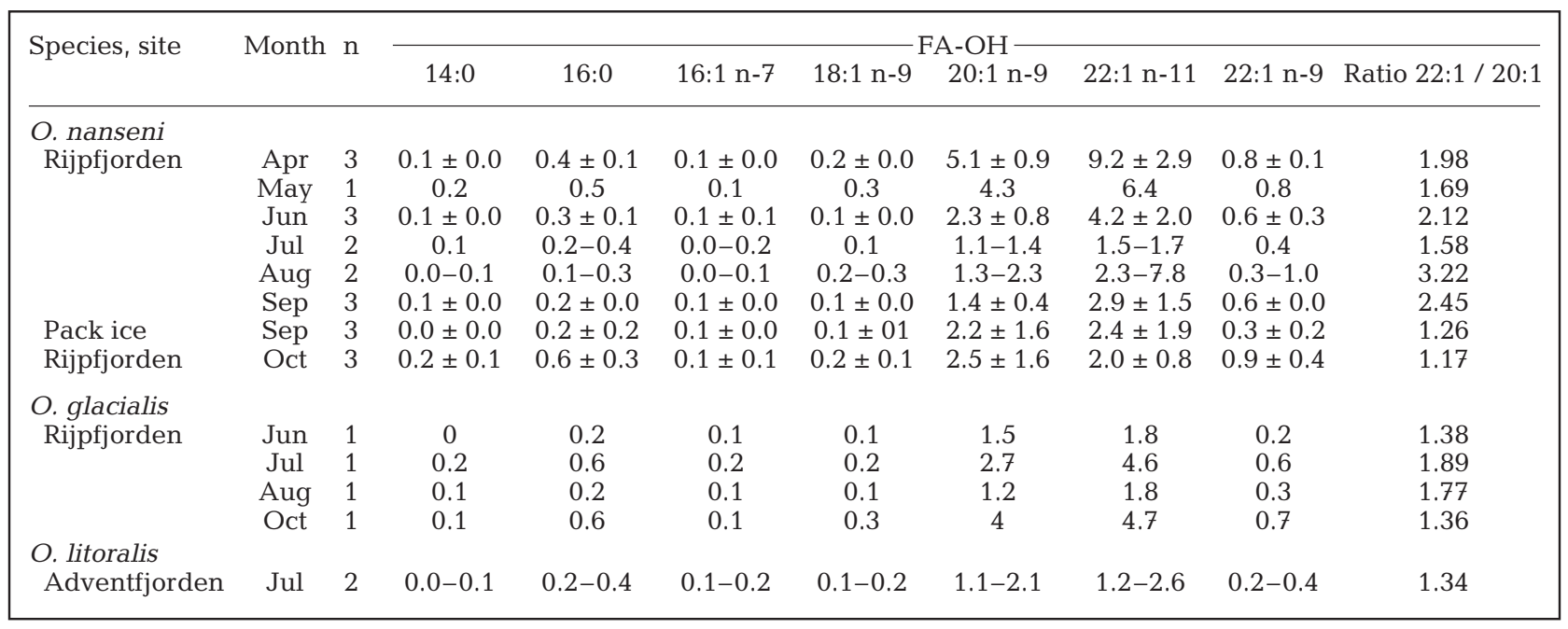


Table 4. Anonyx nugax, Onisimus nanseni, O. litoralis and O. caricus. Stable carbon $\left(\delta^{13} \mathrm{C}\right)$ and nitrogen $\left(\delta^{15} \mathrm{~N}\right)$ isotope values (mean $\pm \mathrm{SD}$ ) and trophic levels $A$. nugax and $O$. nanseni were collected in Rijpfjorden, $O$. litoralis and $O$. caricus in Adventfjorden. n: number of replicate samples

\begin{tabular}{|llllrc|}
\hline Species & Month & $\mathrm{n}$ & \multicolumn{1}{c|}{$\delta^{13} \mathrm{C}$} & \multicolumn{1}{c|}{$\delta^{15} \mathrm{~N}$} & $\begin{array}{c}\text { Trophic } \\
\text { level }\end{array}$ \\
\hline A. nugax & Apr & 4 & $-21.6 \pm 0.4$ & $12.0 \pm 0.7$ & 3.5 \\
& Jun & 4 & $-20.7 \pm 0.5$ & $11.6 \pm 0.6$ & 3.4 \\
& Jul & 3 & $-21.5 \pm 0.6$ & $11.8 \pm 0.3$ & 3.3 \\
& Aug & 3 & $-21.6 \pm 0.6$ & $12.0 \pm 1.5$ & 3.3 \\
& Sep & 4 & $-21.4 \pm 0.4$ & $11.7 \pm 1.1$ & 3.3 \\
& Oct & 6 & $-20.8 \pm 0.4$ & $12.7 \pm 0.8$ & 3.5 \\
O. nanseni & Apr & 5 & $-22.6 \pm 0.5$ & $9.6 \pm 0.6$ & 2.8 \\
& May & 4 & $-22.3 \pm 0.4$ & $10.1 \pm 0.1$ & 2.9 \\
& Jun & 7 & $-22.3 \pm 0.7$ & $9.2 \pm 0.8$ & 2.6 \\
& Jul & 3 & $-21.8 \pm 0.7$ & $9.7 \pm 0.9$ & 2.7 \\
& Aug & 5 & $-21.6 \pm 0.4$ & $10.1 \pm 0.7$ & 2.8 \\
O. litoralis & Apr & 3 & $-21.6 \pm 0.3$ & $9.9 \pm 0.4$ & 2.7 \\
& Jul & 3 & $-22.4 \pm 0.5$ & $6.8 \pm 1.7$ & 1.8 \\
& Aug & 11 & $-21.1 \pm 1.2$ & $10.0 \pm 0.9$ & 2.8 \\
& Sep & 5 & $-22.7 \pm 1.0$ & $8.9 \pm 0.7$ & 2.5 \\
& Oct & 5 & $-22.6 \pm 0.6$ & $8.0 \pm 0.2$ & 2.2 \\
O. caricus & Feb & 5 & $-21.8 \pm 0.4$ & $11.5 \pm 0.7$ & 3.2 \\
& Apr & 3 & $-21.9 \pm 0.6$ & $10.5 \pm 1.6$ & 2.9 \\
& Jun & 3 & $-20.6 \pm 0.6$ & $12.0 \pm 0.7$ & 3.3 \\
& & & & & \\
\hline
\end{tabular}

early November (http://polarview.met.no/), but from then on the fjord was ice free until land-fast ice formed in early February 2007 (Leu et al. 2010). Since the land-fast ice prohibited drift ice entering the fjord, the ice amphipods collected in our study probably originated from the ice that drifted in during autumn, or even earlier. After the ice melt in July 2007, and still in September, O. nanseni could be collected with hand nets nearshore, showing that it can survive outside the ice habitat at least for some months (H. Nygård pers. obs.). A further interesting observation was the high abundance of Anonyx nugax in the ice traps even over depths of $200 \mathrm{~m}$ and kilometers away from shallow areas. A. nugax has been sporadically found in ice (e.g. Melnikov \& Kulikov 1980), but the high abundances of it in ice in the present study suggest that it might utilize the sea-ice habitat more actively than thought.

The difference in the bottom substrate should also be kept in mind when comparing the species composition in the 2 fjords. Onisimus caricus, a species known to inhabit inner fjords disturbed by glacial outflow (Legeżyńska 2001), dominated the scavenging guild on the soft substrate in Adventfjorden, whereas Anonyx spp. dominated on the coarser substrate in Rijpfjorden. A similar pattern, with Onisimus species dominating in inner parts and Anonyx species in outer parts of the fjord, was found in
Kongsfjorden (Legeżyńska 2001). The September samples from Adventfjorden, which were mainly collected in the outer part of the fjord on a substrate more comparable to that in Rijpfjorden, were dominated by Anonyx species. However, the species composition in the September samples from Adventfjorden clusters together with the other Adventfjorden samples, indicating that there is a difference in species composition between the 2 fjords that is not fully explained by differences in type of substrate. The differing temperature and production regimes in the 2 fjords (Søreide et al. 2010, Zajączkowski et al. 2010), resulting from differences in seasonal ice cover, probably constrain the species that can thrive in each fjord.

The clear difference in species composition between depth zones, found in both fjords, can be explained by the depth preferences of different species. This pattern is in accordance with Legeżyńska et al. (2000), who found a depth separation between different Anonyx and Onisimus species: A. nugax and $O$. caricus occurred mainly at depths greater than $30 \mathrm{~m}$ while $A$. sarsi was found mainly in shallower waters; $O$. edwardsii peaked at $15 \mathrm{~m}$ and $O$. litoralis was most abundant at $5 \mathrm{~m}$ depth (Legeżyńska et al. 2000).

In the present study, 2 species that have not been recorded earlier in Svalbard waters were found (Palerud et al. 2004). Both Anonyx pacificus and Onisimus nr. sibiricus were found in Rijpfjorden, an area that until now has not been thoroughly studied. A. pacificus has its main distribution area in the northwest Atlantic (Steele \& Brunel 1968), whereas $O$. sibiricus has until now been found only in the Russian Arctic seas (Berge et al. 2007).

\section{Seasonality in the trap catches}

A clear seasonal difference in the baited trap catches was evident in both Rijpfjorden and Adventfjorden, with, in general, larger catches in winter than in summer. Interestingly, this seasonal variation was not synchronized in the 2 fjords. The highest catches were retrieved in Adventfjorden in November, while in Rijpfjorden the highest abundance was recorded in February. The samples collected in spring, April and May, in Adventfjorden, and early summer, June and July, in Rijpfjorden, contained very few amphipods compared to the samples collected during the rest of the year. The earlier peak and the earlier decrease of amphipods in the traps in Adventfjorden compared to Rijpfjorden can be related to the different environmental conditions i.e. 
the earlier seasonal development of the system in Adventfjorden, with an earlier primary production bloom due to the lack of sea ice (Fig. 3; Søreide et al. 2010, Zajaczkowski et al. 2010). This pattern can be compared to the timing of primary production described on a latitudinal gradient by Leu et al. (2011).

Changes in the amphipods' feeding behavior or preferences influence the baited trap catches (Smale et al. 2007). Thus, the seasonality in the catches does not reflect real differences in the abundances of scavenging amphipods in the fjords. During the winter, food resources are presumably scarce in the fjords, thus a baited trap is likely to be attractive for the amphipods. In contrast, during spring and summer, when primary production and settling of organic material peak, there is an excess of potential food and the amphipods might not be so strongly attracted to the smell of bait. Legeżyńska (2008) suggests a seasonal feeding strategy for Onisimus caricus, i.e. that this species consumes mainly zooplankton carcasses in summer, when they are highly abundant in glacial bays (Zajączkowski \& Legeżyńska 2001). Additionally, during summer, a large proportion of the amphipod populations consist of newly released juveniles that might have different feeding preferences than older stage amphipods (Nygård et al. 2009).

Processes connected to reproduction influence the attractiveness to bait. Mature males increase their swimming activity prior to the mating season and might therefore be more prone to enter traps (SainteMarie 1986, Sainte-Marie et al. 1990, Conlan 1991). Based on earlier observations on brood carrying females, mating in the studied species generally occurs in early winter (Węsławski \& Legeżyńska 2002, Nygård et al. 2009, 2010). The delay of the phytoplankton spring bloom in Rijpfjorden due to the sea ice cover might alter the scheduling of the life cycles in Rijpfjorden compared to Adventfjorden. As the egg sizes in Onisimus and Anonyx species are approximately the same (Sainte-Marie et al. 1990, Węsławski \& Legeżyńska 2002), the embryo development time should be comparable between the species, and thus the main mating period of these species is probably around 2 mo earlier in Adventfjorden compared to Rijpfjorden. In many species, males die shortly after the mating period (SainteMarie et al. 1990, Nygård et al. 2009), which could also be reflected in decreased catches. Sainte-Marie et al. (1990) noted that pregnant females of A. sarsi carrying eggs in their brood pouches contract their gut and stop feeding actively; consequently they would not be attracted to baited traps. Sainte-Marie \& Lamarche (1985) suggest that species attracted to traps while brooding are iteroparous, while semelparous species do not feed while brooding.

A final factor that could have an impact on the behavior or habitat choice of the amphipods is predation pressure, or rather avoidance of predators. As these amphipods are quite large they are probably easy prey for visual predators if they expose themselves to brightly lit areas. In Adventfjorden, the decrease in the catches, especially in the shallow traps, coincides with the time of the year when the light increases and migrating birds return. Seabirds (black guillemots Cepphus grylle, Arctic terns Sterna paradisea, eider ducks Somateria mollissima) feed on amphipods (Węsławski et al. 1994, Byers et al. 2010), as do shore-birds (purple sandpiper Calidris maritima) in the inter-tidal zone (Luukkonen 2009). Interestingly, there is an increase in the trap catches again in June, when the melting season has started and the fjord is receiving high loads of suspended particles. Reduced visibility in the water complicates the foraging of visual predators and may provide favorable conditions for the amphipods to return to the shallower areas. However, this explanation can not explain the decrease in the catches in Rijpfjorden in June, since the fjord was still ice covered and therefore predation from birds is not expected. However, in July, Arctic terns were actively foraging near-shore in Rijpfjorden, probably catching amphipods (H. Nygård pers. obs.). The predation pressure on amphipods by fish and seals (Labansen et al. 2007) remains unknown in our study area.

\section{Feeding patterns}

Based on the stable isotope analyses we were able to assign a trophic position to 4 of the investigated amphipods. Anonyx nugax was the highest positioned species in the food web with a TL of 3.3 to 3.5, followed by Onisimus caricus (2.9-3.3) and $O$. nanseni (2.6-2.9). O. litoralis was the species closest to a herbivore (1.8-2.8) with a clearly herbivorous trophic position (1.8) in July. It should however be noted that whole individuals were used for the stable isotope analyses, which probably underestimates their true trophic level (Søreide \& Nygård 2011).

The stable isotope results strongly support the pattern found in the fatty acid composition, where 3 main groups were identified: (1) a herbivorous/ omnivorous group including Onisimus glacialis and O. litoralis; (2) a carnivorous/scavenging group comprising $O$. caricus, and (3) a Calanus predating group including primarily O. nanseni. Anonyx nugax was situated between groups 2 and 3 (Fig. 6). 
The trophic position of Anonyx nugax, indicated by its isotope signature, fits well with diet signals as interpreted by lipid composition. That it has a carnivorous/necrophagous diet is revealed by its high 18:1 n-9/n-7 ratio (Sargent \& Falk-Petersen 1981, 1988). Anonyx species show typical adaptations necessary for scavenging feeding: the same mouth part characteristics as typical scavenging amphipods in the deep sea (Sainte-Marie 1984, Sainte-Marie \& Lamarche 1985), large size for increased motility (Sainte-Marie 1984), efficient feeding, and large gut size and ability to withstand starvation (Sainte-Marie 1984, SainteMarie et al. 1989). Legeżyńska (2008) identified a size-dependant scavenging mode, where immature individuals of $A$. nugax fed on a variety of food and only mature individuals were true scavengers. Even though A. nugax is ill-equipped for predation, it seems to predate on pelagic crustaceans (SainteMarie \& Lamarche 1985). Based on fatty acid analyses, Graeve et al. (1997) showed that A. nugax probably feeds on calanoid copepods. Similarly, in our study, levels of the typical Calanus FATM were elevated in the autumn, indicating a predatory behavior. These markers, however, decreased in the winter, possibly indicating a more scavenging behavior, as the 18:1 n-9/n-7 ratio was elevated. Thus, the PCA analysis, showing $A$. nugax positioned between the mainly scavenging Onisimus caricus and the mainly Calanus-feeding O. nanseni, confirms that A. nugax is an omnivorous scavenger that seasonally broadens its diet by predating on Calanus. Another interesting feature of the fatty acid composition is the high levels of 22:6 n-3, a well known dinoflagellate FATM (Dalsgaard et al. 2003). The origin of this fatty acid in $A$. nugax remains unknown for the time being.

The individuals collected from the sea ice undersurface had markedly lower lipid content and a reduced proportion of triacylglycerols, indicating that these individuals had a poor nutritional status. As most of the specimens collected in the ice traps were mature males, these could be individuals that, after the reproduction in winter, are about to die, or are actively trying to replenish their energy stores. However, their fate remains unknown for the time being. Similarly, Anonyx sarsi collected below drifting sea ice in the Barents Sea had low lipid content and mostly empty guts, indicating that they migrated to the ice in search for food (Werner et al. 2004).

Both Onisimus glacialis and $O$. nanseni have been described in earlier studies as detrivores, which reduce their niche overlap by using different food sources, with $O$. glacialis primarily using algal material and $O$. nanseni mainly animal remains (Poltermann
2001, Arndt et al. 2005a). Based on our fatty acid results, O. glacialis is clearly separated from O. nanseni in having a high content of the diatom marker 16:1 $\mathrm{n}-7$, while $O$. nanseni is rich in the Calanus markers 20:1 n-9 and 22:1 n-11. A seasonal feeding pattern was found in $O$. glacialis, with a switch from a diet based on diatoms in summer and autumn to a diet including calanoid copepods in winter. In contrast $O$. nanseni appears to feed year-round on calanoid copepods (Werner \& Auel 2005, present study). As shown by Arndt et al. (2005a) O. glacialis shows morphological adaptations to feeding on small particles like diatoms, having a forceps-like dactylus on the second gnathopod, while in $O$. nanseni the dactylus on the second gnathopod is more claw-like and suitable for holding live prey or animal remains. The $\delta^{15} \mathrm{~N}$ ratio in O. nanseni also supports carnivory. Unfortunately we do not have stable isotope values for O. glacialis, but Hobson \& Welch (1992) and Søreide et al. (2006a) placed this species on a TL of 2.2 to 2.7 , slightly lower than our results for $O$. nanseni (2.6-2.9).

Onisimus litoralis is closely grouped with O. glacialis in the PCA analysis; the 2 species being mostly herbivorous/omnivorous. O. litoralis has been shown to utilize the spring bloom intensively, while it probably switches to a more omnivorous diet outside the phytoplankton bloom period (Carey \& Boudrias 1987, Gradinger \& Bluhm 2010). In a feeding experiment, O. litoralis was found to actively feed on dead zooplankton as well as living zooplankton stranded on the bottom (Legeżyńska 2001). Based on its lipid dynamics, Nygård et al. (2010) concluded that $O$. litoralis feeds year-round. In Adventfjorden this species seems to feed on the spring bloom, showing an increased content of the diatom marker 16:1 n-7 in summer, while the amount of the marker for carnivory, 18:1 n-9, decreases. Consequently the $\delta^{15} \mathrm{~N}$ value is lowest in July, when it indicates a trophic level of 1.8, which confirms a predominantly herbivorous diet.

Onisimus caricus seems, based on fatty acid and stable isotope data, to have a rather regular diet during the year. It has constantly a high ratio of 18:1 n-9/n-7, which indicates necrophagy (Bühring \& Christiansen 2001). Legeżyńska (2008) studied the gut contents of $O$. caricus and found a high proportion of crustacean parts in their guts. However, it remains unclear if they were caught by predation or if they were eaten dead from the bottom, as the guts also contained a lot of sediment grains. In a feeding experiment $O$. caricus fed actively on dead copepods, while it only fed on live copepods if they were stranded on the bottom of the aquaria (Legeżyńska 
2001). The structure of its mandibles suggests an efficient consumption of carrion (Legeżyńska 2008) and it is likely that zooplankton is only seasonally important as a food source (Zajączkowski \& Legeżyńska 2001, Legeżyńska 2008, Nygård et al. 2009). In our study, the level of Calanus FATM was quite low in $O$. caricus. However, as we have fatty acid composition data on $O$. caricus only from February, June and November, seasonal feeding on copepods could have been overlooked.

\section{Life cycles}

Generally, Arctic amphipods have a single brood per year and brood release is synchronized with the most favorable conditions, which often is at the onset of the spring algal bloom (Węsławski \& Legeżyńska 2002). Thus, it can be assumed that distinct size classes represent cohorts and by studying the lengthfrequency distribution of populations, life spans and life cycles can be retrieved. Alternatively, species could have multiple broods per year, but this is very rare in the Arctic (Węsławski \& Legeżyńska 2002, Tandberg et al. 2010).

Life cycles of Onisimus species have been described in a number of publications (Boudrias \& Carey 1988, Węsławski et al. 2000, Węsławski \& Legeżyńska 2002, Arndt \& Beuchel 2006, Nygård et al. 2009, 2010). Based on these studies it appears that $O$. litoralis and $O$. nanseni have the shortest life cycles ( 2 yr) and the highest growth rate. In comparison, $O$. glacialis and $O$. caricus have prolonged life cycles (3-5 yr) and a slower growth rate. The differences in growth rate could be explained by different feeding strategies. Based on our fatty acid composition data, O. nanseni seems to be a predator on calanoid copepods in addition to necrophagous feeding (Arndt et al. 2005a), while O. glacialis is more herbivorous and thus more affected by the seasonality in primary production; although Werner \& Auel (2005) suggest the latter species switches to a Calanus diet in winter. O. litoralis is also herbivorous-omnivorous, but it has been shown to feed year-round (Nygård et al. 2010). As a predominantly scavenger species, $O$. caricus is probably the most dependent on sporadic food falls and may therefore have the most unpredictable food source. Thus, $O$. nanseni and $O$. litoralis have feeding strategies that allow them to grow continuously throughout the year, and complete their life cycles in 2 to $2.5 \mathrm{yr}$. Although $O$. glacialis also feeds on detritus and Calanus in winter (Arndt et al. 2005a, Werner \& Auel
2005), it is probably mostly a seasonal feeder on ice algae. It therefore needs to build up lipid reserves (30\% of DW in October) for overwintering and can not afford continuous growth. O. caricus has an unpredictable food source and thus also needs to prioritize survival until the next feeding opportunity, instead of investing energy in growth. These tradeoffs most likely restrict the growth rate of $O$. glacialis and $O$. caricus, so that these species require longer life spans in order to complete their life cycles.

The length-frequency distribution of Onisimus edwardsii indicates 3 cohorts, resulting in a 2 yr life cycle, similar to that earlier suggested for this species (Węsławski \& Legeżyńska 2002). The smallest individuals recorded in February are assumed to be newly hatched, which is surprising since the brood release could be expected to happen during the most productive time of the year. Unfortunately, we did not observe egg-carrying females, but ovigerous females have previously been reported in the period November to May (Węsławski \& Legeżyńska 2002). O. edwardsii is an opportunistic omnivore, feeding on carrion, algae, detritus, meiofauna and crustaceans (Legeżyńska 2001，2008). Thus, this species probably feeds year-round and does not need to build up energy reserves, and could be expected to have a similar life strategy to O. litoralis (Węsławski \& Legeżyńska 2002, Nygård et al. 2010).

For Onisimus brevicaudatus the length-frequency distribution suggests the presence of 3 separate cohorts, implicating a 2 yr life cycle. There is, however, some uncertainty here as we only have sufficient data from one month and the cohorts seem to overlap widely. The wide length span of the cohort, peaking around $0.65 \mathrm{~mm}$ (Fig. 5), could indicate an unsynchronized brood release in this species or large differences in individual growth rates. Alternatively, this cohort could actually consist of 2 cohorts, which we were unable to separate because we had too few observations. In the latter case, a 3 yr life cycle would be suggested. Unfortunately we do not have any information on the feeding strategy of $O$. brevicaudatus, but considering that it was mainly found in deeper parts of Rijpfjorden, it most likely exhibits omnivorous scavenging or predatory behavior. Assuming a scavenging feeding strategy, the growth rate of $O$. brevicaudatus could be comparable to the growth rate of $O$. caricus, which could indicate a $3 \mathrm{yr}$ life cycle. However, further studies on $O$. brevicaudatus are needed to confirm this.

The high abundance of Anonyx spp. juveniles in the September traps reflects the brood release earlier that summer. As we did not catch any egg-carrying 
females in this study, and the overall catches were small in the summer months, we do not have any information on the timing of the brood release for these species. In Adventfjorden, Anonyx spp. juveniles were almost exclusively collected in September. A. nugax is reported to have at least a 4 yr life cycle (Sainte-Marie et al. 1990, Węsławski \& Legeżyńska 2002). It has large eggs (1.6 $\mathrm{mm}$ in diameter) and carries brood between November and June (Węsławski \& Legeżyńska 2002). A. sarsi has been described as having a 2 yr life cycle in the Saint Lawrence Estuary (Sainte-Marie et al. 1990), while it has at least a 3 yr life cycle in Svalbard waters (Węsławski \& Legeżyńska 2002). In Svalbard, it has large eggs $(1.3 \mathrm{~mm}$ in diameter) and has been found to be brood-carrying between November and April (Węsławski \& Legeżyńska 2002). Sainte-Marie et al. (1990) found that the embryo development took $\sim 4$ mo in the Saint Lawrence Estuary, but the eggs here were smaller (1.0 $\mathrm{mm}$ in diameter) than in Svalbard waters and thus probably developed faster (Steele \& Steele 1975).

\section{Conclusions}

A clear difference in the species composition of the amphipod scavenging guild was observed between Adventfjorden and Rijpfjorden. The influence of sea ice was observed in Rijpfjorden with presence of sympagic amphipods, whereas these were not found in Adventfjorden. Another factor contributing to the differences in species composition was the sediment quality, favoring the occurrence of Onisimus species in Adventfjorden on soft substrate and the higher abundance of Anonyx species in Rijpfjorden on coarser substrate.

The baited trap catches varied seasonally in both Adventfjorden and Rijpfjorden, but the timing of the peak in abundance differed. The variations were probably due to ontogenic processes, feeding behavior and/or predator avoidance. The differences in climate between the fjords regulate both the productive period and the timing of life history events in the amphipods.

Three main feeding strategies were observed among the collected amphipods: (1) a herbivorousomnivorous group, consisting of Onisimus glacialis and $O$. litoralis, with high proportions of diatom markers (17-41\%) combined with relatively low $\delta^{15} \mathrm{~N}$ values (mean $8.7 \%$ ); (2) a carnivorous/scavenging group, consisting of $O$. caricus, with particularly high proportion of the fatty acid 18:1n-9 (39-40\%) combined with high $\delta^{15} \mathrm{~N}$ values (mean $11.3 \%$ ), and (3) a Calanus-feeding group, consisting of O. nanseni, characterized by high proportion of Calanus markers $(13-35 \%)$ combined with moderate $\delta^{15} \mathrm{~N}$ values (mean 9.7\%). The fatty acid and stable isotope composition of Anonyx nugax indicated an omnivorouscarnivorous diet. Differences in feeding strategies influence growth rates in the amphipods and thus also life history strategies.

Acknowledgements. We acknowledge the 3 anonymous reviewers, whose constructive comments improved the manuscript. Additionally, we thank E. Leu, J. Wiktor, M. Zajączkowski and K. Berg-Hansen for help during the field work, as well as M. Daase for help with the graphics. This study was funded by Statoil through the StatoilHydroARCTOS Arctic Research Programme.

\section{LITERATURE CITED}

Ambrose WG Jr, Carroll ML, Greenacre M, Thorrold SR, McMahon KW (2006) Variation in Serripes groenlandicus (Bivalvia) growth in a Norwegian high-Arctic fjord: evidence for local- and large-scale climatic forcing. Glob Change Biol 12:1595-1607

Anderson MJ, Gorley RN, Clarke KR (2008) PERMANOVA+ for PRIMER: guide to software and statistical methods. PRIMER-E, Plymouth

> Arndt CE, Beuchel F (2006) Life history and population dynamics of the Arctic sympagic amphipods Onisimus nanseni Sars and O. glacialis Sars (Gammaridea: Lysianassoidae). Polar Biol 29:239-248

Arndt CE, Pavlova O (2005) Origin and faith of ice fauna in the Fram Strait and Svalbard area. Mar Ecol Prog Ser 301:55-66

Arndt CE, Berge J, Brandt A (2005a) Mouthpart-atlas of Arctic sympagic amphipods-trophic niche separation based on mouthpart morphology and feeding ecology. J Crustac Biol 25:401-412

> Arndt C, Fernandez-Leborans G, Seuthe L, Berge J, Gulliksen B (2005b) Ciliated epibionts on the Arctic sympagic amphipod Gammarus wilkitzkii as indicators for sympago-benthic coupling. Mar Biol 147:643-652

Berge J, Vader W, Johnsen JR (2007) Studies on the genus Onisimus Boeck, 1871 (Crustacea, Amphipoda, Uristidae). II. The barentsi and edwardsii groups. Zootaxa 1410:55-68

Berge J, Cottier F, Last KS, Varpe $\varnothing$ and others (2009) Diel vertical migration of Arctic zooplankton during the polar night. Biol Lett 5:69-72

Boudrias MA, Carey AG Jr (1988) Life history patterns of Pseudalibrotus litoralis (Crustacea: Amphipoda) on the inner continental shelf, SW Beaufort Sea. Mar Ecol Prog Ser 49:249-257

Britton JC, Morton B (1994) Marine carrion and scavengers. Oceanogr Mar Biol Ann Rev 32:369-434

Bühring SI, Christiansen B (2001) Lipids in selected abyssal benthopelagic animals: links to the epipelagic zone? Prog Oceanogr 50:369-382

Byers T, Smith A, Mallory ML (2010) Diet of black guillemots and northern fulmars breeding beside a High Arctic polynya. Polar Biol 33:457-467

Carey AG Jr, Boudrias MA (1987) Feeding ecology of Pseudalibrotus (=Onisimus) litoralis Kröyer (Crustacea: 
Amphipoda) on the Beaufort Sea inner continental shelf. Polar Biol 8:29-33

Christie WW (1982) Lipid analysis, 2nd edn. Pergamon Press, New York, NY

> Clarke KR (1993) Non-parametric multivariate analyses of changes in community structure. Aust J Ecol 18:117-143

Clarke KR, Gorley RN (2006) PRIMER v6: user manual/ tutorial. PRIMER-E, Plymouth

> Conlan KE (1991) Precopulatory mating behaviour and sexual dimorphism in the amphipod Crustacea. Hydrobiologia 223:255-282

Dahl E (1979) Deep-sea carrion feeding amphipods: evolutionary patterns in niche adaptation. Oikos 33:167-175

> Dalsgaard J, St John M, Kattner G, Müller-Navarra D, Hagen W (2003) Fatty acid trophic markers in the pelagic marine environment. Adv Mar Biol 46:225-340

Dauby P, Scailteur Y, De Broyer C (2001) Trophic diverstity within the eastern Weddell Sea amphipod community. Hydrobiol 443:69-86

Dauby P, Nyssen F, De Broyer C (2003) Amphipods as food sources for higher trophic levels in the Southern Ocean: a synthesis. In: Huiskes AHL, Gieskes WWC, Rozema J, Schorno RML, van der Vies SM, Wolff WJ (eds) Antarctic biology in a global context. Backhuis Publishers, Leiden, p 129-134

> De Broyer C, Nyssen F, Dauby P (2004) The crustacean scavenger guild in Antarctic shelf, bathyal and abyssal communities. Deep-Sea Res II 51:1733-1752

Folch JM, Lees M, Sloane-Stanley GH (1957) A simple method for the isolation and purification of total lipids from animal tissues. J Biol Chem 226:497-509

Gradinger R, Bluhm B (2010) Timing of ice algal grazing by the nearshore benthic amphipod Onisimus litoralis. Arctic 63:355-358

Graeve M, Kattner G, Piepenburg D (1997) Lipids in Arctic benthos: Does fatty acid and alcohol composition reflect feeding and trophic interactions? Polar Biol 18:53-61

Graeve M, Dauby P, Scailteur Y (2001) Combined lipid, fatty acid and digestive tract content analyses: a penetrating approach to estimate feeding modes of Antarctic amphipods. Polar Biol 24:853-862

Hobson KA, Welch HE (1992) Determination of trophic relationships within a high Arctic marine food web using $\delta^{13} \mathrm{C}$ and $\delta^{15} \mathrm{~N}$ analyses. Mar Ecol Prog Ser 84:9-18

Holm S (1979) A simple sequentially rejective multiple test procedure. Scand J Stat 6:65-70

Hop H, Pavlova O (2008) Distribution and biomass transport of ice amphipods in drifting sea ice around Svalbard. Deep-Sea Res II 55:2292-2307

Jarre-Teichmann A, Brey T, Bathmann UV, Dahm C and others (1997) Trophic flows in the benthic shelf community of the eastern Weddell Sea. In: Battaglia B, Valencia J, Walton DWH (eds) Antarctic communities. Cambridge University Press, Cambridge, p 118-134

Kaluzny MA, Duncan LA, Merritt MV, Epps DE (1985) Rapid separation of lipid classes in high yield and purity using bonded phase columns. J Lipid Res 26:135-140

Labansen AL, Lydersen C, Haug T, Kovacs KM (2007) Spring diet of ringed seals (Phoca hispida) from northwestern Spitsbergen, Norway. ICES J Mar Sci 64: 1246-1256

Legeżyńska J (2001) Distribution patterns and feeding strategies of lysianassoid amphipods in shallow waters of an Arctic fjord. Pol Polar Res 22:173-186

Legeżyńska J (2008) Food resource partitioning among Arctic sublittoral lysianassoid amphipods in summer. Polar Biol 31:663-670
Legeżyńska J, Węsławski JM, Presler P (2000) Benthic scavengers collected by baited traps in the high Arctic. Polar Biol 23:539-544

$>$ Leu E, Wiktor J, Søreide JE, Berge J, Falk-Petersen S (2010) Increased irradiance reduces food quality of sea ice algae. Mar Ecol Prog Ser 411:49-60

> Leu E, Søreide JE, Hessen DO, Falk-Petersen S, Berge J (2011) Consequences of changing sea ice cover for primary and secondary producers in the European Arctic shelf seas: timing, quantity, and quality. Prog Oceanogr 90:18-32

Luukkonen AM (2009) The use of space and food resources by purple sandpipers (Calidris maritima) in a high Arctic estuary in relation to tidal dynamics. MSc thesis, University of Turku

Melnikov IA, Kulikov AS (1980) The cryopelagic fauna of the central Arctic basin. In: Vinogradov ME, Melnikov IA (eds) Biologiya Tsentral'nogo Arkticheskogo Basseina. Akadelniya Eauk SSSR, Nauka Publishing, Moscow, p $97-111$

Moore PG, Wong YM (1995) Activity and trapping characteristics in the field of Orchomene nanus (Krøyer) (Amphipoda: Lysianassoidea) at Millport, Scotland. J Exp Mar Biol Ecol 189:143-157

> Nygård H, Berge J, Gulliksen B, Camus L (2007) The occurrence of Eualus gaimardii gibba Krøyer 1841 (Crustacea, Decapoda) in the sympagic habitat: an example of bentho-sympagic coupling. Polar Biol 30:1351-1354

Nygård H, Vihtakari M, Berge J (2009) Life history of Onisimus caricus (Amphipoda: Lysianassoidea) in a high Arctic fjord. Aquat Biol 5:63-74

Nygård H, Wallenschus J, Camus L, Varpe Ø, Berge J (2010) Annual routines and life history traits of the amphipod Onisimus litoralis: seasonal growth, body composition and energy budget. Mar Ecol Prog Ser 417:115-126

> Nyssen F, Brey T, Dauby P, Graeve M (2005) Trophic position of Antarctic amphipods-enhanced analysis by a 2-dimensional biomarker assay. Mar Ecol Prog Ser 300: 135-145

Oksanen J (2011) Multivariate analysis of ecological communities in R: vegan tutorial. University of Oulu. http:// cc.oulu.fi/ jarioksa/opetus/metodi/vegantutor.pdf

Palerud R, Gulliksen B, Brattegard T, Sneli JA, Vader W (2004) The marine macro-organisms in Svalbard waters. In: Prestrud P, Strøm H, Goldman HV (eds) A catalogue of the terrestrial and marine animals of Svalbard. Norsk Polarinstitutt Skrifter 201:5-56

Pawłowska J, Włodarska-Kowalczuk M, Zajączkowski, Nygård H, Berge J (2011) Seasonal variability of meio- and macrobenthic standing stocks and diversity in an Arctic fjord (Adventfjorden, Spitsbergen). Polar Biol 34:833-845

> Poltermann M (2001) Arctic sea ice as feeding ground for amphipods-food sources and strategies. Polar Biol 24: 89-96

Premke K, Klages M, Arntz WE (2006) Aggregations of Arctic deep-sea scavengers at large food falls: temporal distribution, consumption rates and population structure. Mar Ecol Prog Ser 325:121-135

R Development Core Team (2010) R: a language and environment for statistical computing. R Foundation for Statistical Computing, Vienna

Sainte-Marie B (1984) Morphological adaptations for carrion feeding in four species of littoral or circalittoral lysianassid amphipods. Can J Zool 62:1668-1674

Sainte-Marie B (1986) Feeding and swimming of lysianassid amphipods in a shallow cold-water bay. Mar Biol 91: 219-229 
Sainte-Marie B (1987) Meal size and feeding rate of the shallow-water lysianassid Anonyx sarsi (Crustacea: Amphipoda). Mar Ecol Prog Ser 40:209-219

Sainte-Marie B, Lamarche G (1985) The diets of six species of the carrion-feeding lysianassid amphipod genus Anonyx and their relation with morphology and swimming behavior. Sarsia 70:119-126

Sainte-Marie B, Percy JA, Shea JR (1989) A comparison of meal size and feeding rate of the lysianassid amphipods Anonyx nugax, Onisimus (= Pseudalibrotus) litoralis and Orchomenella pinguis. Mar Biol 102:361-368

Sainte-Marie B, Lamarche G, Gagnon JM (1990) Reproductive bionomics of some shallow-water lysianassoids in the Saint Lawrence Estuary, with a review on the fecundity of the Lysianassoidea (Crustacea, Amphipoda). Can J Zool 68:1639-1644

Sargent JR, Falk-Petersen S (1981) Ecological investigations on the zooplankton community in Balsfjorden, Northern Norway: lipids and fatty acids in Meganyctiphanes norvegica, Thysanoessa raschi and $T$. inermis during mid-winter. Mar Biol 62:131-137

Sargent JR, Falk-Petersen S (1988) The lipid biochemistry of calanoid copepods. Hydrobiologia 167/168:101-114

Slattery PN, Oliver JS (1986) Scavenging and other feeding habits of lysianassoid amphipods (Orchomene spp.) from McMurdo Sound, Antarctica. Polar Biol 6:171-177

Smale DA, Barnes DKA, Fraser KPP, Mann PJ, Brown MP (2007) Scavenging in Antarctica: intense variation between sites and seasons in shallow benthic necrophagy. J Exp Mar Biol Ecol 349:405-417

Søreide JE, Nygård H (2011) Challenges using stable isotopes for estimating trophic levels in marine amphipods. Polar Biol 35:447-453

Søreide JE, Hop H, Carroll ML, Falk-Petersen S, Hegseth EN (2006a) Seasonal food web structures and sympagicpelagic coupling in the European Arctic revealed by stable isotopes and a two-source food web model. Prog Oceanogr 71:59-87

Søreide JE, Tamelander T, Hop H, Hobson KA, Johansen I (2006b) Sample preparation effects on stable C and N isotope values: a comparison of methods in Arctic marine food web studies. Mar Ecol Prog Ser 328:17-28

Søreide JE, Leu E, Berge J, Graeve M, Falk-Petersen S (2010) Timing of blooms, algal food quality and Calanus glacialis reproduction and growth in a changing Arctic. Glob Change Biol 16:3154-3163

Steele DH, Brunel P (1968) Amphipoda of the Atlantic and Arctic coasts of North America: Anonyx (Lysianassidae). J Fish Res Board Can 25:943-1060

Steele DH, Steele VJ (1975) Egg size and duration of embryonic development in Crustacea. Int Revue ges Hydrobiol 60:711-715

Svendsen H, Beszczynska-Møller A, Hagen JO, Lefauconnier B and others (2002) The physical environment of Kongsfjorden-Krossfjorden, an Arctic fjord system in Svalbard. Polar Res 21:133-166

Tandberg AHS, Vader W, Berge J (2010) Studies on the association of Metopa glacialis (Amphipoda, Crustacea) and Musculus discors (Mollusca, Mytilidae). Polar Biol

Editorial responsibility: Hans Heinrich Janssen, Oldendorf/Luhe, Germany

\section{3:1407-1418}

ter Braak CJF (1986) Canonical Correspondence Analysis: a new eigenvector technique for multivariate direct gradient analysis. Ecology 67:1167-1179

ter Braak CJF (1995) Ordination. In: Jongman RGH, ter Braak CJF, van Tongeren OFR (eds) Data analysis in community and landscape ecology. Cambridge University Press, Cambridge, p 91-173

ter Braak CJF, Smilauer P (2002) CANONCO reference manual and CanoDraw for Windows user's guide: software for canonical community ordination (version 4.5). Microcomputer Power, Ithaca, NY

Vader W, Romppainen K (1985) Notes on Norwegian marine Amphipoda. 10. Scavengers and fish associates. Fauna Norv Ser A 6:3-8

> Vader W, Johnsen JR, Berge J (2005) Studies on the genus Onisimus Boeck, 1871 (Crustacea, Amphipoda, Lysianassoidea, Uristidae). I. The brevicaudatus and sextonae species groups. Org Divers Evol 5:161-164

- Wallace MI, Cottier FR, Berge J, Tarling GA, Griffiths C, Brierley AS (2010) Comparison of zooplankton vertical migration in an ice-free and a seasonally ice-covered Arctic fjord: an insight into the influence of sea ice cover on zooplankton behavior. Limnol Oceanogr 55:831-845

> Werner I, Auel H (2005) Seasonal variability in abundance, respiration and lipid composition of Arctic under-ice amphipods. Mar Ecol Prog Ser 292:251-262

Werner I, Auel H, Garrity C, Hagen W (1999) Pelagic occurrence of the sympagic amphipod Gammarus wilkitzkii in ice-free waters of the Greenland Sea-dead end or part of life-cycle? Polar Biol 22:56-60

Werner I, Auel H, Kiko R (2004) Occurence of Anonyx sarsi (Amphipoda: Lysianassoidea) below Arctic pack ice: an example for cryo-benthic coupling? Polar Biol 27: 474-481

Węsławski JM, Legeżyńska J (2002) Life cycles of some Arctic amphipods. Pol Polar Res 23:253-264

Węsławski JM, Kwasniewski S, Wiktor J (1991) Winter in a Svalbard fiord ecosystem. Arctic 44:115-123

Węsławski JM, Stempniewicz L, Galaktionov K (1994) Summer diet of seabirds from the Frans Josef Land archipelago, Russian Arctic. Polar Res 13:173-181

Węsławski JM, Szymelfenig M, Zajączkowski M, Keck A (1999) Influence of salinity and suspended matter on benthos of an Arctic tidal flat. ICES J Mar Sci 56:194-202

Węsławski JM, Opaliński K, Legeżyńska J (2000) Life cycle and production of Onisimus litoralis (Crustacea: Amphipoda): the key species in the Arctic soft sediment littoral. Pol Arch Hydrobiol 47:585-596

Zajączkowski M (2008) Sediment supply and fluxes in glacial and outwash fjords, Konsfjorden and Adventfjorden, Svalbard. Pol Polar Res 29:59-72

Zajączkowski M, Legeżyńska J (2001) Estimation of zooplankton mortality caused by an Arctic glacier outflow. Oceanologia 43:341-351

Zajączkowski M, Nygård H, Hegseth EN, Berge J (2010) Vertical flux of particulate matter in an Arctic fjord: the case of lack of sea-ice cover in Adventfjorden 2006-2007. Polar Biol 33:223-239

Submitted: February 16, 2011; Accepted: November 24, 2011 Proofs received from author(s): January 29, 2012 